\title{
SARRAÏNS DESAVEÏNATS D'ELX A MITJAN SEGLE XV (1449) SEGONS LLUR PROPI TESTIMONI: DIFICULTATS ECONÒMIQUES I CONFLICTIVITAT INTERNA DE LA MORERIA
}

\author{
Roser Salicrú i Lluch*
}

El 1391, l'infant Martí de Sicília va vendre a la ciutat de Barcelona, amb carta de gràcia, la vila d'Elx i el lloc de Crevillent. La venda ha d'inscriure's en el marc dels problemes econòmics que provocà a la monarquia catalanoaragonesa l'empresa italiana de l'Infant Martí, l'expedició a Sicília.

Tot i que Elx i Crevillent foren baronia de Barcelona fins el 1473, a partir del 1459 el municipi va deixar de cobrar les rendes que, en virtut del contracte de 1391, havia de percebre en compensació de la quantitat esmerçada en la compra de les poblacions.

Segons aquest contracte, Elx havia de pagar a la ciutat de Barcelona mil lliures anuals de les seves rendes, i Crevillent cinc-centes, en substitució de les rendes ordinàries d'ambdós llocs, que havien de ser administrades pel Consell d'Elx. Si les rendes ordinàries superaven aquestes quantitats anuals, el romanent havia de ser lliurat a l'Infant Martí però, si no hi arribaven, Elx i Crevillent havien de responsabilitzar-se de la diferència.

Per aquest motiu, la vila d'Elx va signar uns capítols en els quals es comprometia a pagar les 1000 lliures anuals en dos terminis, l'un per Nadal i l'altre per Sant Joan, tot admetent que si no podia arribar a satisfer aquesta quantitat li fos feta execució de béns.

Aquestes 1500 lliures anuals havien de considerar-se el rèdit de les 27.500 lliures que Barcelona havia pagat per la compra de la baronia. Tanmateix, la ciutat catalana podia tenir, a la vegada, ingressos complementaris (drets judicials i drets senyorials en totes les alienacions que es fessin d'aquest tipus de béns) i despeses, ocasionades pel pagament dels salaris dels administradors que gestionaven la baronia per la ciutat. De fet, la pos-

* Departament d'Estudis Medievals, Institució Milà i Fontanals - CSIC. 
sessió de la baronia provocà al municipi de Barcelona una complexa problemàtica jurídica i econòmica ${ }^{1}$.

Encara que la documentació processal del quatre-cents conservada als arxius catalans en general i barcelonins en particular que fa referència als sarraïns que vivien en terres de la Corona catalano-aragonesa no sigui, ni de lluny, tan rica ni abundant com la del segle anterior, $i$ en especial la de l'Arxiu de la Corona d'Aragó ${ }^{2}$, la compra d'Elx i Crevillent per part del municipi de Barcelona explica que a l'Arxiu d'Història de la Ciutat s'hi hagin conservat alguns documents que fan referència a les aljames d'aquests dos llocs que, algunes vegades, ens permeten captar la veu dels seus sarraïns.

És notori que, al llarg del segle $X V$, les comunitats sarraïnes de la Corona d'Aragó es trobaven en un procés de decadència cada cop més perceptible. Els segles de domini cristià havien anat debilitant els seus costums i les seves estructures, i les dissensions internes no hi eren gens estranyes. I més si tenim en compte que aquestes comunitats islàmiques normalment estaven formades per camperols que, sotmesos a la pressió fiscal de la Corona o dels senyorius jurisdiccionals, ja tenien prou feina per subsistir.

Aquesta pressió fiscal estava inevitablement associada, quan esdevenia del tot insostenible, amb l'emigració dels sarraïns cap a d'altres territoris on tenien l'esperança, sovint més il.lusòria que real, de poder seguir vivint i treballant amb càrregues fiscals i en condicions econòmiques menys feixugues ${ }^{3}$.

Encara que els senyors, constantment preocupats per l'abandonament de les terres i les consegüents pèrdues econòmiques que els ocasionava l'emigració dels sarraïns, intentessin fer tot allò possible per obtenir mesures restrictives de la seva mobilitat, els sarraïns catalano-aragonesos disposaven de plena llibertat per canviar de lloc de residència a l'interior de les fronteres de la Corona.

1. Vegeu J.-F. CabeStany i Fort, J. SObrequés i Callico, «Elx i Crevillent, baronia de Barcelona (1391-1473). Notes i documents per al seu estudi», dins Primer Congreso de Historia del Pais Valenciano. Valencia, 1971, volum II, València, Universitat de València, 1980, 625-638, i M.T. FERRER I MALLOL, Les aljames sarraïnes de la Governació d'Oriola en el segle XIV, Barcelona, CSIC-Institució Milà i Fontanals, 1988, 40-42. Específicament sobre Crevillent, J. HiNOJOSA MONTALVO, "Crevillente: una comunidad mudéjar en la Gobernación de Orihuela en el siglo XV», dins IV Simposio Internacional de Mudejarismo: Economía. Teruel, 1987, Teruel, Instituto de Estudios Turolenses, 1992, 307-317; IDEM, «La gestión de la renta feudal en Crevillente durante el siglo XV», ibidem, 319-337.

2. Recordem que, el 1419, es va crear 1'Arxiu del Regne de València.

3. El despoblament de les aljames del regne de València, almenys a les terres de la Governació d'Oriola, va esdevenir, des de la Pesta Negra, un problema crònic. Vegeu M.T. FERRER I MALLOL, Els sarraïns de la Corona catalano-aragonesa en el segle XIV. Segregació i discriminació, Barcelona, CSIC - Institució Milà i Fontanals, 1987, 105-135. Per al cas aragonès, vegeu P. PÉREZ VIÑuALES, "Presión fiscal y emigración: algunos ejemplos de aljamas mudéjares aragonesas», dins Actas del $V$ Simposio Internacional de Mudejarismo. Teruel, 13-15 de septiembre de 1990, Teruel, Instituto de Estudios Turolenses, 1991, 75-86. 
Només durant la Guerra dels Dos Peres, concretament el 1360, sabem que quedaren prohibits els canvis de residència, fins i tot entre dos llocs del patrimoni reial, per evitar l'abandonament de les terres. Però aquesta mesura també va afectar, a més d'als sarraïns, als cristians vassalls d'algun senyor.

De tota manera, sempre es van concedir algunes llicències particulars per canviar de domicilit.

Hi havia una resistència especial per a permetre la mobilitat de les dones, sobretot si eren solteres, perquè eren un element important per mantenir o incrementar la població de cada lloc ${ }^{5}$.

Els béns que els sarraïns es podien endur en canviar de residència era sempre el punt més conflictiu. No obstant això, no hi havia cap reglamentació general referent a això, i podia variar segons els costums de cada indret.

Malgrat tot, els senyors intentaven impedir sovint als moros que es traslladaven que s'emportessin llurs béns mobles per intentar evitar que marxessin.

Garant dels seus drets, la Corona defensava sempre, en casos particulars, els sarraïns que eren molestats en aquest sentit. I sempre recordava a qui els tenia per vassalls que els havia de respectar llurs franqueses, especialment la llibertat de canviar de lloc de residència i de vendre, abans de fer-ho, els béns que tinguessin a l'indret que abandonaven, mentre paguessin els seus deutes i no sortissin dels seus regnes ${ }^{6}$.

En general, els trasllats de residència dels sarraïns foren prou freqüents, i podien obeir a diverses raons.

Podem destacar, per exemple, diverses menes de calúmnies, com les acusacions de relacions sexuals amb cristianes o de crims que no havien comès i que podien suposar-los la confiscació de béns. $O$ també la coacció de les autoritats cristianes quan visitaven les moreries i preguntaven sobre llurs possessions sense donar-ne a conèixer els motius. Unes altres vegades, els moros podien canviar de residència a causa de la inobservància dels privilegis de què gaudien, o dels abusos dels oficials cristians.

Però un dels motius fonamentals, nodrit per l'esperança de prosperar en altres parts, fou, sempre, la misèria ${ }^{7}$.

Encara que des dẻ mitjan segle XIV, després de la Pesta Negra, es van intensificar els esforços per retenir o atraure moros als senyorius o a les aljames de les ciutats mitjançant les rebaixes de les seves obligacions o contribucions fiscals, no sembla que aquestes mesures fossin sempre suficients.

\footnotetext{
4. M.T. FERRER, Els sarraïns..., 119.

5. Ibidem, 120 .

6. Ibidem, 120-122.

7. Ibidem, 122-126.
} 
La despoblació d'Elx, en concret, havia preocupat a la Corona almenys des de mitjan segle XIV, després de la Guerra dels Dos Peres.

El 1361, la reina Elionor, com a tutora del seu fill, l'Infant Martí, senyor del lloc, ja va intentar atraure nous pobladors a l'aljama per compensar les pèrdues ocasionades per la guerra. Concedí franqueses de peites, almagrams, sofres i altres impostos al llarg de quatre anys als moros que s'establissin a Elx o a Crevillent si es comprometien a viure-hi durant vint anys. El batlle els assignaria terres de conreu i casa. Un cop transcorreguts aquests quatre anys, haurien de pagar els mateixos impostos que la resta de sarraïns.

A més, per evitar que els moros que ja hi residien en marxessin, hagué de perdonar a les aljames d'Elx i de Crevillent els deutes contrets fins el 1361, perquè estaven del tot arruïnats a causa de la guerra, però també per fer front a les ofertes dels senyors de frontera, que havien fet concessions semblants o millors i que suposaven un greu risc per a la despoblació del lloc.

Tanmateix, aquestes concessions no degueren ser suficients per als habitants d'Elx i de Crevillent, perquè, el 1367, el rei va prohibir que els altres llocs de patrimoni reial admetessin els sarraïns procedents d'aquestes comunitats que $n^{\prime}$ havien fugit clandestinament per no pagar els impostos que devien a l'Infant Martí 8 .

La moreria d'Oriola, que havia quedat abandonada a causa de la guerra, esdevingué, des de la fi del segle XIV i fins al moment que ens ocupa, mitjan segle $\mathrm{XV}$, una competència deslleial i preocupant per a les d'Elx i Crevillent. La seva reconstrucció data d'aquests moments. Hi ha constància que alguns dels seus primers habitants procediren, justament, d'Elx. Però, sobretot, són incomptables les notícies que fan referència a qüestions entre Elx i Oriola pels constants impediments, molèsties, traves i extorsions que el procurador i el batlle d'Elx imposaven als moros d'Elx aveïnats a Oriola.

Arribaren fins a tal punt, que el batlle general de la Governació d'Oriola va pactar, el 1447, una concòrdia amb el procurador i el batlle d'Elx per regular les relacions dels desaveïnats d'Elx establerts a Oriola amb la seva antiga població.

Tanmateix, aquesta concòrdia no va acabar amb els problemes i, almenys fins a principis de la dècada dels cinquanta del segle $X V$, segueixen trobant-se queixes per les vexacions del procurador i del batlle $d^{\prime} E l x$, que vetaven l'entrada a la vila als sarraïns aveïnats a Oriola i els ocupaven llurs béns ${ }^{9}$.

8. Ibidem, 126-127.

9. A. Nieto FernáNDeZ, «La morería de Orihuela en el siglo XV», dins Primer Congreso de Historia del País Valenciano..., 761-771. 


\section{LA VILA I L'ALJAMA D'ELX}

Després d'haver estat sota dependència directa de la Corona al llarg del primer quart del segle XIV, la vila d'Elx, rica i important i amb diverses alqueries, formà part de diversos heretatges de membres de la família reial. Això, que la separà del patrimoni reial, permeté també, de fet, el seu retorn a la Corona diverses vegades, perquè suposava una situació especial ${ }^{10}$.

Encara que les xifres d'habitants sarraïns d'Elx que es coneixen no siguin prou segures per realitzar estudis demogràfics, permeten de constatar, comparant-les amb les dels altres llocs, que Elx fou, almenys al llarg de la major part del segle XIV, el nucli sarraí més important de les terres de la Governació d'Oriola ${ }^{11}$. L'abundància de privilegis i de disposicions reials a favor de l'aljama n'és una altra mostra.

L'horta d'Elx era la més rica de la Governació dellà Xixona. Els sarraïns hi tenien assignada una part que s'anomenava el Magram o l'Almagram, regada per la sèquia de Marxena. Encara que a l'horta hi havia oliveres, segurament també devia haver-n'hi a les terres de secà ${ }^{12}$.

El raval sarraí d'Elx era situat a la part meridional de la ciutat, a l'entorn de la mesquita. Sembla que la majoria dels seus habitants vivien de l'agricultura i treballaven, a cens del rei o senyor del lloc, les terres de la part del terme anomenada Magram. Però l'aljama sarraïna del raval d'Elx no era l'única del terme de la vila. Molts dels sarraïns vivien a l'Horta, on hi havia una altra mesquita $i$, tot $i$ que algunes de les alqueries habitades per sarraïns pertanyien a l'aljama d'Elx, probablement n'hi havia d'altres que formaven aljama a part, si més no a la segona meitat del segle XIV ${ }^{13}$.

Com les altres aljames, la d'Elx era regida per un consell de vells, presidit per un cadí. Segons Ibarra, i tal com ens permetran corroborar els nostres documents, a Elx el consell de vells estava format per dos jurats, que s'ocupaven de l'administració general ${ }^{14}$ i que, normalment, eren citats amb el nom de vells ${ }^{15}$, equivalent al de jurats o al d'adelantats de l'aljama ${ }^{16}$.

10. M.T. FERrER I MALLOL, Les aljames..., 11-12, 34-42.

11. Ibidem, 50-52.

12. Ibidem, $85-86,88$.

13. Ibidem, 60, 64-65.

14. P. Ibarra $Y$ Ruiz, Historia de Elche, Alacant, Vicente Botella, 1895 (edició facsímil publicada a Elx, Manuel Pastor Torres Editor, 1982), 75.

15. M.T. FERrER, Les aljames..., 61.

16. M.V. Febrer ROMAGUERA, «Antecedentes y configuración de los consejos de viejos en las aljamas de moros valencianas», dins Actas del V Simposio Internacional de Mudejarismo..., 147169; IDEM, "Las morerías valencianas y la organización de sus aljamas», Anales de la Real Academia de Cultura Valenciana. Segunda Época, 67 (1991), 124. 
Una de les seves tasques principals devia haver estat la de repartir els impostos de 1'aljama entre els veïns, i és molt probable que haguessin estat també els encarregats de decidir el repartiment de talles per a subvenir a les despeses extraordinàries de la comunitat.

El 1317, Jaume II concedí als sarraïns del raval d'Elx que aquest repartiment de talles pogués ser anual, però disposà, a causa de les dissensions constants que solia provocar, que hi intervingués el batlle general dellà Xixona o un representant seu. Com que, segons sembla, els vells es perpetuaven en el càrrec i s'enfranquien a ells i a llurs parents de l'impost de l'alfarda, el 1318 el rei decidí que els vells encarregats de repartir els impostos haguessin de canviar cada any i que només poguessin gaudir de franquesa de cabeçatge i d'alfatrà durant l'exercici del càrrec. Però, com que el sistema nou encara provocà més queixes, el 1321 hom retornà al tradicional; tanmateix, el monarca recomanà al batlle general que vigilés que els vells obtinguessin franquícia d'impostos només per raó de llur ofici, i que no enfranquissin llurs parents ${ }^{17}$.

El cadí o alcadí, una altra autoritat bàsica en el funcionament de l'aljama, compta amb notícies molt més abundants. Sembla, en principi, que era nomenat pel rei o pel senyor del lloc, i que rebia el salari del procurador d'aquest senyor, és a dir, de les rendes senyorials ${ }^{18}$.

\section{ELS DOS INFORMES DEL 1449}

Els dos informes que presentem sobre el desaveïnament de diversos sarraïns de l'aljama d'Elx, de l'estiu del 1449, són testimoni de totes aquestes dificultats.

A través de les seves pròpies declaracions davant del procurador general i del lloctinent de batlle de Barcelona o dels jurats de la vila, els moros fan palesos llurs problemes fiscals i econòmics. Però, a més, també van deixant aflorar, de manera més o menys explícita segons les circumstàncies, una sèrie de queixes que posen de manifest els conflictes latents a l'interior de l'aljama $i$, en especial, l'enfrontament entre l'alfaquí i l'alcadí i llurs partides o bàndols respectius.

Descobrim finalment que, per sobre de tot, els sarraïns d'Elx són menys capaços de fer front a les alfardes que els imposa llur alfaquí per despeses que ells consideren supèrflues que no pas al pagament de les rendes de senyoriu a la ciutat de Barcelona.

17. M.T. FERRER, Les aljames..., 61-62. Cf. també M.V. FEBRER, Antecedentes..., 162.

18. Ibidem, 62. Vegeu també M.V. Febrer ROMAGUera, «Los tribunales de los alcadies de moros en las aljamas mudéjares valencianas», Anuario de Estudios Medievales, 22 (1992), 45-77; IDEM, «La administración económica de las aljamas mudéjares valencianas a través del estudio del oficio de alamín», dins IV Simposio Internacional de Mudejarismo..., 261-279. 
A més, els sarraïns d'Elx es queixen de la connivència de llurs pròpies autoritats amb els oficials cristians, ja que no se'ls aplica justícia segons llur sunna i xara sinó segons la voluntat del procurador i del batlle de la vila, fet que agreuja, encara més, llur precarietat econòmica, perquè han de pagar despeses innecessàries que llur propi sistema judicial els estalviaria.

Descobrim, per tant, aquest malestar constantment latent a la moreria que no tan sols ja ha fet que molts sarraïns en marxin sinó que està a punt de desencadenar la partença de molts d'altres, disposats a fugir-ne si les autoritats cristianes, realment alarmades, no es decideixen a posar-hi remei.

El primer informe dels dos que analitzem data del 16 de juny de 1449 , i recull el testimoni de cinc sarraïns de la moreria d'Elx que aquell mateix dia o l'anterior havien presentat al lloctinent de batlle de la vila d'Elx per la ciutat de Barcelona albarà de veïnatge a Albatera o a la Daia, aldees d'Oriola ${ }^{19}$.

Havent sabut que el dia abans diversos moros de la moreria de la vila havien presentat albarans de veïnatge i s'havien fet veïns dels llocs esmentats, Joan Fernández de Mesa, regent de l'ofici de la procuració general de la vila d'Elx i del lloc de Crevillent per la ciutat de Barcelona, i Galceran Olivera, lloctinent d'Antoni Balaguer, batlle de la vila d'Elx i del lloc de Crevillent per la ciutat de Barcelona, es presentaren a la moreria d'Elx amb voluntat de proveir-hi, per conèixer les causes que els havien impulsat a marxar i per evitar que altres sarraïns fessin el mateix.

Abans, s'havien entrevistat amb Gabriel Serradell, lloctinent de receptor de les rendes de la ciutat de Barcelona, resident a la vila d'Elx.

Acompanyats de Joan Gómez, notari i escrivà de la procuració i de la batllia de la vila, i de Bernat Queixans i Fernando Javaloyes, que actuaren com a testimonis, reberen informació dels cinc sarraïns, sota jurament i a la mesquita, en presència d'Hamet Albarrani, vell i jurat de la moreria, i de Çaat Beoquexa, lloctinent de Cilim Zaem, l'altre vell de la moreria.

Tres dels sarraïns (Mahomat Bornocia, àlies Marvà, Amet Barrani i Mahomat Izmil) s'havien traslladat a Albatera, $i$ els dos restants (Çaat Catmar, àlies Castelló, i Axer Tureytes) a la Daia.

Hom els preguntà, a tots ells, per quina raó havien marxat de la moreria, i si algú els havia induit a fer-ho. Finalment, se'ls va oferir la possibilitat

19. Sobre la Daia, vegeu J.A. BARRIO BARRTo, «El señorío de la Daya y el municipio de Orihuela en el siglo XV», dins E. SARASA SÁNCHEZ, E. SERRANO MARTín (eds.), Señorío y feudalismo en la Península Ibérica (ss. XII-XIX), vol. III, Saragossa, Institución Fernando el Católico, 1993, 259-270. Sobre Oriola i les seves aldees, M.T. FerRer, Les aljames..., 6-11, 55-60, 94 i ss; J.B. VILAR, Historia de la ciudad de Orihuela, vol. III, Los siglos XIV y XV en Orihuela, Múrcia, Patronato Ángel García Rogel - Obra Social de la Caja de Ahorros de Nuestra Señora de Montserrat -Obra Social de la Caja de Ahorros de Alicante y Murcia, 1977; A. NIETO, «La morería...», 761-771; J.A. BARRIO BARRIO, El ejercicio del poder en un municipio medieval: Orihuela 1308-1479, Alacant, Universitat d'Alacant, 1993 (tesi doctoral editada en micro-fitxes). 
de prorrogar-los els deutes si acceptaven tornar a Elx, però només dos d'ells $\mathrm{s}^{\prime}$ hi mostraren disposats.

Després d'escoltar llurs declaracions, el procurador i el lloctinent de batlle notificaren que el lloctinent de receptor de les rendes (amb qui s'havien entrevistat i a instància del qual el collidor importunava els moros perquè paguessin els deutes de la paga del Nadal anterior) s'havia mostrat disposat, en presència dels jurats de la vila, a concedir pròrrogues a tots els sarraïns que, bonament, no poguessin pagar els deutes derivats d'aquella paga.

Tot seguit, disposaren que, per tal que tots els moros se'n poguessin assabentar, es fes, immediatament, una crida a la vila per notificar-los-ho.

La crida, incorporada al document després de les declaracions, fou feta aquell mateix dia per Jaume Crespo, toca-trompeta i missatger del procurador i del lloctinent de batlle.

La crida feia saber a tots els moros veïns d'Elx que tinguessin deutes amb la senyoria de la vila o amb el collidor de les rendes de la paga de Nadal anterior, que el procurador i el lloctinent del batlle prorrogarien els deutes a tots els sarraïns que es presentessin davant seu a sol-licitar-ho. Altrament, si els interessats no es dirigien a ells, la manca de pròrroga hauria de considerar-se culpa seva, perquè ni el procurador ni el lloctinent del batlle no sabien qui eren les persones que n'estaven necessitades.

El segon document que analitzem aplega catorze declaracions més. La informació, en aquest cas, fou iniciativa dels jurats d'Elx. Les primeres declaracions són, també, del 16 de juny del 1449, però el testimoniatge dels sarraïns s'allarga fins al 23 de juliol del mateix any.

La informació fou rebuda per dos dels jurats de la vila d'Elx, Francesc Governa i Pere Quirant, que uns dies abans, durant un consell general a la sala o torre de la vila, havien rebut l'encàrrec de fer comparèixer els moros que s'havien fet veïns d'altres parts i els que volien marxar per informar-se de les raons que els havien impulsat a abandonar la vila, amb la intenció de comunicar-les als consellers de Barcelona perquè hi proveïssin com consideressin més convenient.

Davant les proporcions que semblava que podia adquirir l'emigració de sarraïns, el consell d'Elx estava alarmat. De fet, la despoblació de l'aljama els devia afectar directament en el pagament de les rendes a Barcelona, perquè, com ja ho hem dit, Elx pagava a la ciutat una quantitat fixa anual. Per tant, és possible que la mobilitat dels moros perjudiqués els cristians, perquè podia afectar llur tributació.

Davant dels jurats d'Elx, els sarraïns no declararen sota jurament, sinó tan sols davant de cristians veïns d'Elx que actuaren com a testimonis.

Dels catorze sarraïns que comparegueren davant dels jurats, nou foren interrogats i cinc presentaren clam, segons sembla per pròpia iniciativa, tot advertint els jurats que si no proveïen en les seves queixes marxarien de la vila. 
A diferència dels moros que havien comparegut davant del procurador i del lloctinent de batlle a la mesquita, els jurats d'Elx només preguntaren als nou sarrains que havien abandonat la moreria per quin motiu havien marxat. Tot i això, les seves respostes són molt més detallades que les dels sarraïns del primer document.

Sis d'aquests nou sarraïns (Masquema, Abdalla Ronceret, Axer Tureytes, Adducarim, Çaat Abençaot i Çaat Abençof) se n'havien anat a la ciutat d'Oriola; Mahomat Porruig, àlies Marvà, havia anat a la Daia; Hamet Albarrani, a Albatera; l'altre, Çaat Tureytes, digué que pensava marxar, però no on pensava traslladar-se.

Els altres cinc sarraïns que comparegueren i presentaren clam davant dels jurats d'Elx, quatre homes i una dona, encara eren veïns d'Elx. Tots excepte la sarraïna Zoayra (que era la muller de l'alcadí de la moreria, Ali Abençat Abençaot), manifestaren llur voluntat d'abandonar la vila si els jurats no satisfeien adequadament llurs queixes i peticions. Tres d'aquests sarraïns (Milich Xaep, Çaat Albarrazi i Yuceff Alcadi) havien estat membres del consell de l'aljama ${ }^{20}$ de l'any anterior, i estaven obertament enfrontats amb la partida o bàndol de l'alfaquí, que sembla que era qui dominava l'aljama. De l'altre moro, Amet Sarria, només en sabem que era veí d'Elx.

Un cop acabada la informació, segurament el mateix dia 23 de juliol, data de les darreres declaracions, i un cop llegida davant del Consell d'Elx, es va produir, al Consell, un gran rebombori, però el document no ens indica si fou només entre cristians o si hi havia també alguns sarraïns.

El fet és que hi hagué una gran discussió sobre la conveniència o no de trametre la informació a Barcelona tal i com havia estat rebuda; alguns s'hi negaven, al-legant que els sarraïns no havien declarat sota jurament.

Durant la discussió, Pere Codines, àlies Sepulcre, lloctinent de Jaume Serradell, receptor de les rendes de la vila, va exigir que, en virtut del seu ofici, li fos donat trasllat de la informació, perque la volia enviar personalment als seus senyors, els consellers de Barcelona, per tal que hi proveïssin. A més, volgué destacar i que constés en acta que ell, en nom del receptor, en consells generals anteriors s'havia ofert moltes vegades, $i$ ara ho feia de nou, a esperar-se tant de temps com fos necessari per cobrar els drets dels moros que se'n volguessin anar de la vila si marxaven perquè no podien pagar les rendes de senyor i si, d'aquesta manera, podia evitar-ho.

El seu interès per destacar-ho és, sens dubte, conseqüència de les declaracions en sentit contrari dels sarraïn, que l'acusaven unànimament, tant a ell com al col-lector, $d$ 'importunar-los perquè paguessin, i que el responsabilitzaven, d'aquesta manera, de llurs trasllats a d'altres indrets.

20. Vegeu més avall. 
Entre els moros que declaren a la mesquita i els que ho fan al consell només dos poden ser les mateixes persones. Diem poden perquè, encara que els seus noms coincideixin, llurs declaracions són notablement diferents davant dels uns i davant dels altres.

Tanmateix, és molt probable que, en tots dos casos, es tracti dels mateixos sarraïns. Encara que llur testimoni sigui diferent, res no ens impedeix de considerar-lo complementari. I, si observem les característiques generals de les declaracions en un i altre document, segurament podem explicar les aparents divergències en funció de davant de qui es presta la declaració.

La pràctica totalitat dels sarraïns interrogats atribueixen a la pressió fiscal a la que eren sotmesos llur abandonament de la moreria. Però, mentre que, al primer document, davant del procurador i del lloctinent de batlle $i$, sobretot, davant dels vells de l'aljama, consideren que el principal factor causant de llurs deutes són les rendes de senyor que han de pagar a Barcelona (sense oblidar, tanmateix, la pressió fiscal de l'aljama), els que declaren al segon document, davant dels jurats d'Elx, es queixen, sobretot, de les alfardes de la moreria, i en cap cas només de les rendes de senyor.

Sembla evident, per tant, que davant dels seus propis vells els sarraïns no declaren amb total llibertat, se senten coaccionats.

Podem apreciar quelcom semblant en relació amb un altre dels aspectes en els que més incideixen les declaracions davant dels jurats: els abusos en l'administració de la justícia per part del procurador i del batlle. Directament davant d'aquests dos, a la mesquita, al primer document, es produeix un mutisme absolut. Els sarraïns no gosen queixar-se, per por a represàlies. En canvi, al segon document, davant del Consell de la vila, els acusen repetidament, perquè els jurats d'Elx no es troben directament implicats en l'afer.

Per tant, sia perquè uns declaren sota jurament i uns altres no, sia perquè uns $i$ altres se senten coaccionats de manera diversa o en diferent grau, sia perquè segueixen les pautes marcades per aquells que els han precedit en les declaracions, el cert és que, tant en l'un com en l'altre document, la veu dels sarraïns queda mediatitzada. Encara que no menteixin, en cada cas callen la part de la veritat que podria perjudicar-los.

El primer dels dos sarraïns que apareix als dos documents és Amet o Hamet Barrani o Albarrani ${ }^{21}$, traslladat, segons declara en ambdues ocasions, a Albatera.

Al primer document, Albarrani digué que havia marxat d'Elx perquè no podia pagar al collidor els drets de senyor, $\mathrm{i}$ també a causa de les despeses que feia la moreria, després de reconèixer, però, que abans de presentar l'albarà de veïnatge havia pagat els seus deutes al collidor. Tanmateix, al segon

21. Al primer document també hi apareix un altre sarraí anomenat Hamet Albarrani, un dels dos vells i jurats de la moreria, que assisteix a les declaracions dels moros a la mesquita. 
document, Albarrani va negar que hagués marxat d'Elx perquè no podia pagar els almagrams a la senyoria de la vila, ja que, segons ell, si treballava els podia pagar; afirmà, en canvi, haver partit a causa de les grans despeses que, per culpa dels grans plets que menava la moreria, li tocava pagar.

L'altre nom que coincideix a les declaracions dels dos documents és el d'Axer Tureytes. Al primer, Tureytes digué haver marxat a la Daia a causa dels molts drets a senyor que havia de pagar, que li impedien fer front als seus deutes. A més, admeté que, com que el collidor de les rendes l'importunava constantment $i$ li venia les bèsties, havia demanat a Gabriel Serradell, lloctinent de receptor, que li prorrogués una mica els deutes, perquè havia estat malalt; però tant el collidor com el receptor s'havien negat a fer-ho. Afegí que, amb gran afany i treball, havia aconseguit pagar-los 100 sous, però encara els en devia 120, i no els podia pagar de cap manera. Finalment, també advertí que la moreria feia moltes despeses que tampoc no podia pagar.

En canvi, al segon document, Axer Tureytes apareix com a veí d'Oriola, no de la Daia. Digué, aleshores, que el collidor de l'any anterior, anomenat Antequera, l'havia amenaçat d'empresonar-lo perquè no li podia pagar els deutes i que, si ja li costava pagar les rendes a Barcelona, a sobre encara li exigien les alfardes que feia carregar l'alfaquí pels fets de la moreria, que no podia pagar de cap manera.

Els dinou testimonis de sarraïns que recullen els dos documents ens aporten un gran nombre de dades disperses sobre múltiples aspectes tant dels moros i de l'aljama d'Elx com de l'aparell administratiu cristià i dels mecanismes de funcionament del senyoriu de Barcelona.

Hem reproduït el contingut de les declaracions de tots aquests sarraïns, més o menys sistematitzades però conservant l'estructura original dels documents, als tres quadres gràfics que adjuntem al final de l'estudi.

Tot seguit, intentarem sistematitzar analíticament alguns dels aspectes que recullen, però només a partir del contingut de les declaracions, prescindint de l'estructura documental.

\section{ESTRUCTURA ADMINISTRATIVA I FISCAL CRISTIANA I BARCELONINA A ELX}

La documentació ens permet saber que, l'estiu del 1449, el procurador o regent de la procuració general de la vila d'Elx i del lloc de Crevillent per la ciutat de Barcelona era el donzell Joan Fernández de Mesa. Ja ho havia estat, prèviament, del juliol del 1435 al del 1436 i del setembre del 1439 a l'agost del 1448, i ho tornaria a ser, com a mínim, entre el febrer del 1453 i el desembre del 1456 . 
Sabem que, l'agost del 1448, va ser nomenat procurador d'Elx i Crevillent Ramon Savall; però no va arribar a actuar perquè, a finals de desembre d'aquell any, fou elegit conseller de Barcelona. És, segurament, per això que, l'estiu del 1449, encara trobem a Fernández de Mesa regint l'ofici. De fet, degué exercir-lo fins que, el setembre del 1449, fou substituït per Pere de Relat ${ }^{22}$.

El batlle de la vila d'Elx i del lloc de Crevillent per la ciutat de Barcelona era Antoni Balaguer, però a la documentació només veiem actuar el seu lloctinent, Galceran Olivera.

Per altra part, també se cita, en una ocasió, al llarg del testimoniatge de Çaat Abençof, l'assessor de la batllia.

Pel que fa a l'aparell fiscal, trobem, en primer lloc, el receptor de les rendes de la vila d'Elx per la ciutat de Barcelona, Jaume Serradell.

Això no obstant, gairebé sempre actua algun dels seus lloctinents. Al primer document hi apareix un altre Serradell, Gabriel, que podria ser fill seu, resident a Elx, actuant com a lloctinent de receptor, tot i que els moros, en llurs declaracions, l'anomenin sempre receptor. Al segon document, en canvi, apareix com a lloctinent de receptor de Jaume Serradell un cert Pere Codines, àlies Sepulcre.

Però el responsable directe de la recaptació, a les ordres del receptor o del seu lloctinent, era el collidor o col-lector, que importunava directament els sarraïns endeutats i els confiscava els béns si no podien pagar. Tanmateix, la concessió de les pròrrogues depenia del receptor.

Les declaracions dels sarraïns es refereixen constantment al collidor, però no ens en donen el nom. En canvi, sabem que el de l'any anterior, 1448, s'anomenava Antequera.

D'entre els jurats de la vila d'Elx de l'any 1449 només podem esmentar els dos que reben la informació dels sarraïns del segon document, Francesc Governa i Pere Quirant.

El notari i escrivà del consell i jurats d'Elx era Pere de Llorca, i el de la procuració i de la batllia Joan Gómez.

El missatger i toca-trompeta del procurador i del lloctinent de batlle de la vila era Jaume Crespo.

Finalment, sabem que l'arrendador de la Daia, una de les aldees d'Oriola on havien emigrat diversos moros, era Francesc Peris.

La resta de cristians que apareixen a la documentació (que són degudament relacionats al llistat de noms cristians que incloem com a apèndix) són veïns de la vila d'Elx que actuen com a testimoni de les declaracions dels di-

22. J.-F. CABESTANY, J. SOBREQUés, «Elx i Crevillent...», 630. 
versos moros davant dels jurats d'Elx o davant del procurador i del lloctinent de batlle de la vila. Entre ells podem destacar un forner, Pere Fernández, i un sastre, Bartomeu Granyana.

\section{ESTRUCTURA, DISSENSIONS INTERNES I DIVISIÓ SOCIAL DE L'ALJAMA}

Com ja hem dit, l'aljama sarraïna d'Elx tenia dos vells o jurats ${ }^{23}$.

El primer document ens permet saber que el juny del 1449 eren Amet Albarrani i Cilim Zaem. A més, també veiem actuar un lloctinent d'aquest darrer, anomenat Çaat Beoquexa, que, el 16 de juny, va presenciar, en nom del seu principal, a la mesquita, davant del procurador i del lloctinent de batlle de la vila, les declaracions dels cinc sarraïns.

Per altra part, entre els sarraïns que, al segon document, presenten clam davant dels jurats d'Elx, n'hi ha tres que es defineixen com "un dels deu de l'aljama de l'any anterior", és a dir, de l'any 1448.

Gràcies a un document que fa referència a la introducció de la insaculació a la moreria d'Elx per part de les autoritats barcelonines per acabar amb les seves dissensions ${ }^{24}$ (del que no sabem la data precisa però que coincideix amb algun dels períodes de procuradoria de Fernández de Mesa ${ }^{25}$ ), podem saber que, a més dels dos vells, l'aljama d'Elx tenia, en aquells moments, un consell de deu membres.

Com a garant de les llibertats de la població sarraïna d'Elx i davant de les possibles agressions i abusos a causa de les constants rivalitats partidistes en el govern de l'aljama il-licitana, la ciutat de Barcelona va intentar solucionar la inestabilitat mitjançant la provisió dels seus càrrecs públics per insaculació. Aquest sistema s'havia establert per primer cop en una ciutat de la confederació catalano-aragonesa el 1427, a Xàtiva ${ }^{26}$, però fins fa ben poc es desconeixia

23. Vegeu el text corresponent a les notes 14,15 i 16.

24. Vegeu J.D. GARRIDO I VALLS, «Barcelona senyora de mudèjars: la introducció de la insaculació a la moreria d'Elx per les autoritats barcelonines», dins III Congrés d'història de Barcelona. La ciutat i el seu territori, dos mil anys d'història, volum I (Ponències i Comunicacions), Barcelona, Institut Municipal d'Història, 1993, 177-180.

25. De tota manera, com que la part introductòria d'aquest document esmenta alguns plets que podrien ser els que relaciona l'aportació de Maria Teresa Ferrer i Mallol en aquest mateix Col-loqui, Dissensions a la moreria d'Elx a mitjan segle XV, el document deu ser coetani o posterior al $1453 \mathrm{i}$, per tant, del darrer període conegut de procuradoria de Fernández de Mesa (febrer del 1453 - desembre del 1456) (vegeu el text corresponent a la nota 22). Si fos així, hauríem de concloure que el consell dels deu de l'aljama era anterior a la introducció de la insaculació en la provisió dels càrrecs de l'aljama.

26. Vegeu J.M. TORRAS I RIBÉ, «El procedimiento insaculatorio en los municipios de los reinos de la Corona de Aragón entre la renovación institucional y el sometimiento a la monarquía 
la seva instauració en el govern de les aljames musulmanes, indubtable influència de la política municipal barcelonina a les seves possessions.

Segons aquest document, a la fi de cada any els dos vells de l'aljama d'Elx de l'any que acabava havien de designar quatre homes bons de més de seixanta anys que havien d'insacular els noms de tots els moros que consideressin hàbils i suficients per regir i administrar la cosa pública de la moreria.

El primer divendres després de Cap d'Any, a la mesquita de la moreria, en presència del procurador, del batlle de la vila, de l'alcadí $\mathbf{i}$ dels vells, un infant menor de set anys havia d'extreure del sac quatre paperetes i lliurarles al batlle. Entre aquests quatre noms, el batlle n'hauria d'agafar dos, que serien els dels vells del nou any. Els dos restants serien els dos primers membres del consell dels deu de l'aljama. Posteriorment, s'havien de treure sis albarans més del sac. Aquests sis, afegits als dos primers que no havien estat designats com a vells $i$ als dos vells de l'any anterior, formarien el consell dels deu de l'aljama del nou any ${ }^{27}$.

Amb tot el que hem dit fins ara, ja ha quedat ben palès que, a mitjan segle $X V$, l'aljama sarraïna d'Elx es trobava dividida en dos bàndols.

Un d'ells, el que tenia més poder el 1449, era capitanejat per l'alfaquí. Alguns testimonis li oposen, en referència a alguns plets, l'alcadí, però no tenim cap notícia concreta dels motius que havien generat llur enfrontament, tot $i$ que sabem que, en algun moment no massa llunyà, enviaren missatgeries oposades a Barcelona.

En canvi, allò que es fa més evident és el desacord entre l'alfaquí i els membres del consell dels deu de l'aljama de l'any anterior que presenten les seves queixes davant dels jurats d'Elx, és a dir, Milich Xaep, Çaat Albarrazi i Yuceff Alcadi. Tots tres, encara que sigui a través de testimonis sorprenentment simètrics, acusen l'alfaquí i els de la seva part d'actuar a l'esquena de la resta de l'aljama. Si donem crèdit a Milich Xaep, que parla per ell i per altres cinc de l'aljama, podem deduir que, el 1448, el consell estava format per sis membres detractors de l'alfaquí i quatre del seu partit.

Encara que la nostra documentació no esmenti en cap cas el nom de l'alfaquí, és gairebé segur que es tractava de Mahomat Alhaig, protagonista, el 1453, de les dissensions a la moreria que planteja l'aportació de Maria Teresa Ferrer i Mallol en aquest Col-loqui, i que també és mencionat com a opositor de l'alcadí a la part preliminar del document d'introducció de la insaculació a l'aljama ${ }^{28}$.

(1427-1714)», dins Actas del I Congreso Internacional Jerónimo Zurita. Su época y su escuela, Saragossa, CSIC-Institución Fernando el Católico, 1986, 341-352; J.A. BARRIO BARRIO, «La introducción de la insaculación en la Corona de Aragón. Xàtiva, 1427. Transcripción documental», Anales de la Universidad de Alicante, 8 (1990-1991 [1992]), 99-114.

27. J.D. GARRIDO, «Barcelona...», 177-180.

28. Cf. M.T. Ferrer i Mallol, Dissensions..., J.D. Garrido, «Barcelona...». 
L'alcadí era Ali Abençat Abençaot. Les declaracions dels sarraïns tampoc no l'anomenen, però coneixem el seu nom a través del testimoni de la seva dona, Zoayra.

Allò que sí anomena la documentació, diverses vegades, són les conseqüències nocives dels debats entre l'alfaquí i l'alcadí, a causa de les grans despeses que havia provocat, sobretot el primer, en correus i missatgeries a Barcelona.

La part introductòria del document d'introducció de la insaculació, que concorda plenament amb les dades que aporten els nostres testimonis i els de Maria Teresa Ferrer i Mallol, ens permet saber, en primer lloc, que, a causa de les disputes que hi havia a la moreria, havien anat a Barcelona l'alcadí de la moreria, Ali Abençahot, acompanyat de Çahat Sarria, d'una part, i l'alfaquí Mahomat Alhaig, acompanyat de Çahat Benzacaria, d'una altra; en segon lloc, diu que els moros de la moreria d'Elx pledejaven els uns contra els altres fent grans despeses que els feien perdre els jornals, i també ens permet saber que un dels elements en discussió eren les grans despeses en escriptures i advocats que havia ocasionat l'alfaquí; finalment, descobrim que l'alfaquí havia intentat interferir en els afers de l'alcadí i que, per això, se li havia ordenat que s'ocupés únicament del espiritual e no del temporal, tot i que l'ordre (segurament relacionada, altra volta, amb l'afer que presenta Maria Teresa Ferrer, perquè fa referència directa a la salä ${ }^{29}$ ) posteriorment fos revocada ${ }^{30}$.

Com que, segons el testimoni dels tres que el 1448 pertanyien al consell dels deu de l'aljama, l'alfaquí i els del seu bàndol sempre havien actuat d'esquena a la resta del consell, això, a més del lògic malestar en el govern de la moreria, havia provocat que els membres del consell detractors de l'alfaquí rebessin nombroses queixes del poble o de la gent menuda, que, essent membres del consell, els responsabilitzava, lògicament, dels problemes, encara que ells els diguessin que no en sabien res perquè l'alfaquí sempre actuava pel seu compte.

Les declaracions dels membres del consell de l'aljama coincideixen, en aquest sentit, amb el testimoni d'altres sarraïns que diuen que els de l'aljama s'ho fan tot entre ells, com és el cas d'Amet Sarria, o d'Adducarim, que diu no saber res dels fets de la moreria tot i que li carreguin alfardes.

En darrer terme, entre els càrrecs o oficials de l'aljama, podem saber que la moreria d'Elx comptava amb un mostassaf. Yuceff Alcadi, un dels deu de l'aljama de l'any 1448, explica que durant el seu exercici havien elegit, com era costum i amb consentiment del batlle, Çaat Albarrazi com a mostassaf. Però, quinze dies després que hagués començat a exercir el càrrec, l'alfaquí aconseguí fer revocar la seva elecció. Un dels deu de l'aljama de l'any

29. Vegeu M.T. FERRER, Dissensions...

30. J.D. GARRIDO, «Barcelona...». 
1448 que presenta clam davant dels jurats d'Elx el dia 23 de juliol, el mateix dia que ho fa Yuceff Alcadi, es diu Çaat Albarrazi, com el mostassaf. Encara que fóra possible que es tractés d'una mateixa persona, seria estrany que, en tot cas, no es lamentés d'una acció que l'afectava tan directament.

\section{DADES FISCALS I IMPOSITIVES}

Els diversos testimonis de sarraïns distingeixen molt clarament que estan subjectes a una doble fiscalitat: les rendes o drets de senyor i les alfardes de l'aljama.

D'allò que havien de pagar a Barcelona, la part que els devia correspondre del que els jurats d'Elx anomenen les rendes planes, n'havien de respondre, com ja ho hem dit, davant del collidor i del receptor.

Els deutes de l'estiu del 1449 provenen del pagament de Nadal de l'any 1448. Recordem que la vila d'Elx havia signat uns capitols en els quals es comprometia a pagar les 1000 lliures anuals en dos terminis, l'un per Nadal i l'altre per Sant Joan, tot admetent que si no podia arribar a satisfer aquesta quantitat li fos feta execució de béns ${ }^{31}$.

Per tant, resulta plenament significatiu que la qüestió dels sarraïns desaveïnats esclati a principis de juny, és a dir, només uns dies abans que els moros que encara tenien deutes del semestre anterior haguessin de fer front a un nou pagament.

Només en quatre ocasions trobem menció explícita d'alguns dels impostos concrets de senyor: l'almagram ${ }^{32}$ i les alfardes ${ }^{33}$, al llarg de l'interrogatori de Mahomat Bornocia, àlies Marvà; la capitació o cabeçatge ${ }^{34}$, en la declaració de Mahomat Izmil; i, de nou, l'almagram, en el cas d'Hamet Albarrani i de Çaat Tureytes.

Els sarraïns del primer document que ja havien emigrat coincideixen unànimament en dir que el collidor de Barcelona els perseguia i els importunava constantment perquè paguessin. A alguns d'ells, com Çaat Catmar, àlies Castelló, Mahomat Izmil o Axer Tureytes, els havia venut muls i bèsties a càrrec dels deutes. I, a Tureytes, l'havia amenaçat, a més, d'empresonar-lo.

31. Vegeu el text corresponent a la nota 1.

32. Vegeu R.I. Burns, Colonialisme medieval. Explotació postcroada de la València islàmica, València, Tres i Quatre, 1987, 143-147; M.T. FerRer, Les aljames..., 133-138; J. Hinojosa MonTAlvo, «Señorío y fiscalidad mudéjar en el Reino de Valencia», dins Actas del V Simposio Internacional de Mudejarismo..., 127.

33. R.I. Burns, Colonialisme..., 167-187; M.T. FERrer, Les aljames..., 123-130; J. HinojosA, «Señorío...», 125.

34. M.T. FERrER, Les aljames..., 130-133; J. HiNojosA, «Señorío...», 125-126. 
Alguns dels sarraïns donen dades concretes sobre les quantitats que deuen o que paguen. Mahomat Bornocia havia pagat, fins al juny del 1449, 100 sous de drets a senyor al collidor, però encara li'n devia 40. Çaat Catmar havia de pagar a un cert Joan Vives 61 sous i, quan havia marxat cap a la Daia, l'arrendador del lloc, Francesc Peris, li havia prestat 20 florins ${ }^{35}$ perquè pogués pagar, abans de fer-ho, tots els seus deutes a Elx. Axer Tureytes havia aconseguit pagar al collidor 100 sous de deutes, però encara li'n restaven a pagar 120, i no sabia com fer-s'ho. En canvi, Amet Barrani havia aconseguit pagar tots els seus deutes abans de marxar cap a Albatera.

Tot i que abans de decidir marxar a altres indrets alguns d'aquests sarraïns havien intentat obtenir demores i pròrrogues per pagar els deutes, havien topat, sistemàticament, amb la negativa del collidor i del receptor, actitud que, com ja ho hem dit, contrasta clarament amb la seva disponibilitat per atorgar ajornaments quan ja s'han produit els desaveïnaments i l'alarma dels cristians.

Çaat Catmar, àlies Castelló, per exemple, havia demanat intercessió a l'aljama, després de comunicar-li que el collidor l'importunava perquè pagués, però l'aljama li havia dit que el procurador no hi podia fer res, perquè era el receptor qui assetjava el collidor perquè el fes pagar. Axer Tureytes havia pregat directament al receptor que, tenint en consideració que havia estat malalt, li prorrogués una mica els deutes, però tant ell com el collidor s'hi havien negat.

En canvi, els lloctinents de receptor es mostraren del tot disposats a prorrogar els deutes, tant quan el procurador general i el lloctinent de batlle parlaren amb ells, el 16 de juny del 1449, com al consell dels jurats d'Elx; en el darrer cas, com ja ho hem vist, Pere Codines fins i tot féu constar en acta que ell, moltes vegades, s'havia mostrat disposat i s'havia ofert a prorrogar els deutes dels sarraïns per evitar que marxessin d'Elx.

És comprensible, per tant, que, un cop fora de la vila i havent obtingut veïnatge en altres parts, aquests mateixos sarraïns a qui, directament, quan més ho necessitaven, havien negat la possibilitat d'allargar els deutes, no tinguessin cap interès per tornar a Elx en ser-los oferta la pròrroga si ho feien. Dels cinc sarraïns del primer document, només dos acceptaren tornar-se'n a Elx si els oferien l'allargament dels deutes. De fet, Çaat Catmar, per exemple, ja havia obtingut, aleshores, un préstec de l'arrendador de la Daia i havia contret, d'aquesta manera, nous deutes amb ell.

35. El florí d'or d'Aragó, emprat com a moneda de compte, tenia un valor nominal d'11 sous de moneda de Barcelona. Aquest valor era, de fet, el que li havia assignat Pere el Cerimoniós, que es mantingué fins als reajustaments monetaris de 1455, quan passà a valer 13 sous, el valor real que li assignava el mercat. Cf. M. CRUSAFONT I SABATER, veu florí dins Diccionari d'Història de Catalunya, Barcelona, Edicions 62, 1992, 467-468; IDEM, Numismàtica de la Corona catalano-aragonesa mediezal (785-1516), Madrid, Vico Editorial, 1982, 109, 111; J. BOTET I SiSO, Les monedes catalanes, Barcelona, Puvill Editor, 1976 (edició facsímil), vol. II, 240. 
En ser preguntats sobre si algú els havia induït a marxar d'Elx, tots ells, unànimament, respongueren que no, tot $\mathrm{i}$ que és difícil de creure que no haguessin estat temptats. El cas de Catmar, a qui l'arrendador de la Daia havia prestat vint florins, sembla ben clar. Però, per altra part, també hem de tenir en compte que un dels requisits per obtenir albarà de veïnatge en algun lloc era l'existència de fiadors d'aquest mateix lloc, cosa que significa que tots els sarraïns que havien canviat de domicili tenien contactes més o menys estrets amb els sarraïns de les aljames d'altres contrades que els havien acollit ${ }^{36}$.

Entre els impostos administrats pels cristians, trobem, en darrer terme, en l'interrogatori a Çaat Abençof, que havia marxat a viure a Oriola, una menció als drets de duana ${ }^{37}$. El duaner li havia interposat un plet per una qüestió sobre drets de duana, que no fa explícita, per valor de 30 sous.

Pel que fa a la tributació de la moreria, trobem constants al.lusions a les alfardes ${ }^{38}$ que llançava o que carregava l'alfaquí per despeses no habituals $i$, segons un dels testimonis, supèrflues.

En concret, s'esmenten alfardes pels plets entre alfaquí i alcadí; per correus i missatgeries a Barcelona; per una donació de 20 florins a Ramon Savall (el procurador elegit el 1448 que no va arribar mai a exercir el càrrec); i per les despeses fetes per a la revocació del mostassaf, que superaven els 200 reials de València ${ }^{39}$.

Tot això confirma que l'alfarda, designada, de vegades, amb els noms cristians de peita, pedido o qüèstia, era, en efecte, com ja apuntava Maria Teresa Ferrer ${ }^{40}$ en contrast amb l'opinió de Robert Ignatius Burns ${ }^{41}$, un impost comunitari. Però, encara que hi pogués haver una alfarda fixa de caràcter anual, la nostra documentació fa evident que, per subvenir a les seves necessitats extraordinàries, l'aljama $i$, en el nostre cas concret, a causa de la influència que havia assolit, l'alfaquí, estava capacitat per emetre, crear o llançar, segons el llenguatge de la documentació, noves alfardes cada vegada que li convenia, l'import de les quals era repartit o carregat després sobre els sarraïns de la moreria.

36. Vegeu l'albarà de veïnatge que publica M.T. FERRER, Dissensions...

37. Generalment, hom usava el nom de duana i quirat per designar l'impost que gravava l'entrada i sortida de mercaderies de les viles del regne de València dellà Xixona que pagaven els sarraïns, i el d'almoixerifat per designar el que pagaven els cristians. Vegeu M.T. FERRER, Les aljames..., 146-153; J. HiNOjOSA, «Señorí...», 123-124; sobre el dret de duana a Elx, J. Hinojosa MONTALVO, «Un arancel comercial en Alicante y Elche durante la Baja Edad Media: el derecho de aduana», Anuario de Estudios Medievales, 23 (1993), especialment 67-74.

38. Sobre l'alfarda, remetem a la bibliografia citada a la nota 33.

39. Deu tractar-se, segurament, de reials o rals d'argent de València, que podrien equivaler a 11 diners cadascun. Cf. M. CRUSAFONT, Numismàtica..., 112.

40. M.T. FERRER, Les aljames..., 123-130.

41. Cf. R I. Burns, Colonialisme..., 167-187. 


\section{DADES ECONÒMIQUES}

Els diversos testimonis ens permeten entreveure la realitat de l'existència d'una oligarquia a l'aljama, diferenciada d'allò que els propis testimonis denominen la gent menuda o el poble, que es lamenta i que ha d'acabar emigrant.

Al marge dels quadres administratius de l'aljama, Çaat Abençof és l'únic que sembla poder-se diferenciar econòmicament de la resta dels seus coreligionaris.

Sembla evident que aquest sarraí, el que tenia el plet pendent per drets de duana, contràriament a la majoria dels que declaren, no devia dedicar-se a l'agricultura sinó, segurament, al comerç. A més, gaudia d'una situació econòmica molt superior a la de la resta. Només cal recordar que els drets de duana disputats ascendien a 30 sous, una quantitat que podia ser equivalent als deutes que motivaven l'emigració de molts dels sarraïns, i ressaltar que, per les despeses del plet, el batlle li havia fet vendre una cortina de seda que tenia que li havia costat 12 florins.

Majoritàriament camperols, els sarraïns ja estaven prou atrafegats per pagar els drets de senyor i les despeses de la moreria, i no podien permetre's desprendre quantitats semblants en articles de luxe.

Segurament, gairebé tots els sarraïns que declararen l'estiu del 1449 vivien, o malvivien, de l'agricultura. Per això deixen traspuar algunes dades relacionades amb llur activitat.

Mahomat Bornocia, àlies Marvà, confessà, per exemple, que aquell any no havia pogut collir res més que 5 cafissos de civada i 5 cafissos de blat, perquè hi havia hagut una gran sequera.

Mahomat Izmil, tot i que tenia una heretat a l'Horta dels Moros de la vila, no era pas més afortunat; la gent li feia camí pel mig de la propietat $i$, encara que se n'havia queixat, no hi havia manera que pogués obtenir justícia.

Çaat Tureytes també posseïa, des de feia nou o deu anys, una heretat al terme de la vila d'Elx. La seva heretat contenia un oliverar, però el batlle l'hi havia pres, l'havia donat a un cert Acen Mocatden i no podia aconseguir que l'hi retornessin.

\section{ELS PROBLEMES JUDICIALS}

Rera les queixes econòmiques i fiscals, l'aspecte que més preocupa els sarraïns d'Elx que han emigrat o que estan a punt de fer-ho és la solució dels seus problemes judicials. 
Llurs protestes en aquest sentit prenen tres direccions: en primer lloc, la no aplicació de la llei sarraïna, la sunna i xara ${ }^{42}$, i el fet que siguin jutjats per oficials cristians, que ocasiona despeses judicials que els moros creuen innecessàries perquè serien evitables si fossin jutjats pels seus propis oficials; en segon lloc, la manca de voluntat per resoldre els plets per part de les autoritats cristianes; $i$, en darrer terme, la connivència de les autoritats sarraïnes, $i$ en especial de l'alfaquí, amb els oficials cristians.

Una de les queixes més clares per la no aplicació de la sunna i xara és la de la dona de l'alcadí de la moreria, Zoayra. Zoayra es lamentà, davant dels jurats d'Elx, de què el procurador i el batlle li haguessin confiscat els béns del seu acidac al-legant que pertanyien al seu marit, l'alcadí, tot i que, segons la llei sarraïna, els béns de la dona no havien de respondre pels del marits, perquè eren propietat d'ella i ningú no els podia tocar ni fer vendre. Per això va sol-licitar als jurats $d^{\prime}$ Elx que parlessin amb el procurador $i$ el batlle perquè li fessin justícia i la jutgessin segons sunna i xara.

L'acidac era el dot i escreix que rebien les dones musulmanes dels seus futurs marits quan es casaven ${ }^{43} i$, en efecte, els béns que això suposava corresponien a la dona en propietat. Encara que s'haguessin de lliurar en el moment del casament, les dificultats econòmiques del futur marit acostumaven a provocar un pagament ajornat del total ${ }^{44}$. Com a béns propis de les sarraïnes, els béns de l'acidac els donaven, en teoria, una independència mínima. Tanmateix, el cert és que els marits solien incorporar l'acidac entre els seus béns personals. Això feia que, després de la mort del marit, fos molt difícil diferenciar l'acidac de la dona i l'herència dels fills. Però, com sembla que succeeix en el cas de Zoayra, els acidacs eren sovint confiscats quan els marits eren penalitzats per algun delicte. Tot i que en teoria les dones no havien de respondre necessàriament amb els seus béns quan els seus pares o parents eren sentenciats de confiscació, els exemples i queixes en sentit contrari són molt abundants ${ }^{45}$.

42. Tot $\mathrm{i}$ que es refereixin a aspectes o a al-legacions que, específicament o explícita, no constin ni apareguin regulats al Llibre de la sunna i xara. Vegeu C. BARCELO (ed.), Un tratado medieval de derecho islámico: el Llibre de la çuna e xara dels moros, Córdova, Universidad de Córdoba, 1989. Vegeu també M.V. FEBrer ROMAGUERA, «La organización judicial de las aljamas mudéjares valencianas y la "Suna e xara"», dins Crónica del XIII Congreso Nacional de Cronistas de España y XVI Asamblea de Cronistas Oficiales del Reino de Valencia, I, València, 1988, 193-217.

43. C. BARCELO (ed.), Un tratado..., 15-16, capítol 57.

44. Aquest és el sistema que apareix al formulari de les capitulacions matrimonials transcrites $\mathrm{i}$ traduïdes per W. HOENERBACH, «El notariado islámico y el cristiano. Estudio comparativo», Cuadernos de Historia del Islam, 11 (1984), 122-123; cf. A. DOMINGO I GABRIEL, La crininalitat entre els sarraïns de la Corona d'Aragó en el segle XIV, Barcelona, Universitat de Barcelona, 1993, tesi doctoral inèdita, vol. II, 765 .

45. Vegeu-ne els exemples que aporta A. Domingo, La criminalitat..., vol. II, 524-525, 766-770. 
Per altra part, el sarraí Çaat Abençof, el que pledejava pels drets de duana, es va queixar perquè el batlle li havia confiscat i malvenut la cortina de seda de 12 florins per tan sols 5 florins. Se'n lamentava perquè, per ell, segons sunna i xara, era costum que els béns de moros es venguessin a estimar durant vuit dies.

Pel que fa a la manca de voluntat de resolució dels plets de sarraïns per part de les autoritats cristianes, podem esmentar, en primer lloc, les queixes de Çaat Tureytes. Com hem dit, Tureytes posseïa una heretat amb un oliverar al terme de la vila d'Elx. Sense, segons ell, cap motiu aparent, el batlle l'hi havia pres i l'havia lliurat a un altre sarraí, Acen Mocatden. Tot i que Çaat havia requerit diverses vegades al batlle que li fes justícia i que li retornés l'oliverar, sempre s'hi havia negat rotundament.

Sense fer cap mena de precisió, Çaat Abençaot també es va lamentar, davant dels jurats $\mathrm{d}^{\prime} \mathrm{Elx}$, del fet que, tot i que moltes vegades hagués demanat justícia d'alguns actes al procurador i al batlle, no la pogués obtenir.

Un altre tema recorrent són les despeses innecessàries que la resolució dels plets davant de les autoritats cristianes ocasionava als sarraïns.

Çaat Abençof és qui en fa una exposició més clara. Segons ell, les grans vexacions i burbulls o agitació que, dia rera dia, es produien tant a la moreria de la vila com a la cort del batlle, ocasionaven grans despeses d'ambdues parts. Deia que de les coses que havia de jutjar l'alcadí se'n feien fer actes a l'escrivà de la batllia perquè aquest n'obtingués ingressos. Com que importunaven constantment els sarraïns per aquestes despeses innecessàries, fins i tot va arribar a produir-se una mena de motí o tumult. Una colla de sarraïns que el mateix Abençof, acompanyat per quinze moros més, degué capitanejar, es va presentar davant del procurador, del batlle i de l'assessor de la batllia per requerir-los que els jutgessin segons llur propia llei, al-legant que els judicis davant de cristians els ocasionaven despeses innecessàries que podrien estalviar-se si eren jutjats segons sunna i xara, perquè, de fet, ells ja tenien un alcadí salariejat. ells.

La resposta del procurador i el batlle fou contundent: volien jutjar-los

I, de forma igualment contundent i ben gràfica, afegiren que, si no hi estaven d'acord, tenien tres camins i podien agafar, immediatament, el que volguessin: el que conduïa a Oriola, el que anava a Alacant i el que menava a la Vall.

De fet, Abençof acabà per fer-los cas, ja que es traslladà a Oriola.

Abençof exposà també la seva experiència personal respecte a aquestes despeses judicials que considerava innecessàries. És a ell a qui el duaner havia posat un plet davant el batlle per la qüestió sobre drets de duana que ascendien a 30 sous; segons ell, el seu cas podia haver-se determinat sense despeses i segons costum de moros i, en canvi, el batlle pretenia fer-li pagar 
10 florins per les despeses del plet. És per això que li confiscà i malvengué la ja esmentada cortina de seda.

Els conflictes de jurisdicció i de competència en l'administració de la justícia baix-medieval, amb un rera-fons econòmic clar, són constants a la documentació, i no només en aquella que fa referència a la justícia musulmana ${ }^{46}$.

Encara que els exemples que fan referència als privilegis de les comunitats islàmiques siguin abundants i malgrat les contínues queixes de les aljames, és un fet que la justícia cristiana es va anar imposant sobre la musulmana en tot tipus de causes.

Anna Domingo considera que una de les característiques que millor s'observa en el segle XIV és la progressiva pèrdua de capacitat de les aljames. L'apropiació de la justícia en les causes mixtes pot ser un fet fàcilment explicable per la diferent qualitat jurídica d'ambdues comunitats, però el problema principal es produí quan els oficials cristians començaren a interferir en aquelles causes en què, específicament, s'havien privilegiat els oficials sarraïns ${ }^{47}$.

Tanmateix, com mostren els nostres testimonis, aquest procés no es va pas fer sense la resistència musulmana, encara que no sempre, també ho veiem aquí, aquesta oposició fos la dels oficials sarraïns. La principal estratègia de resistència que va organitzar la població islàmica es va concretar en la conservació material i memorística dels privilegis concedits durant els primers anys de submissió i en la protesta continuada davant dels excessos dels oficials cristians, tot i que en algunes ocasions també hi hagi mostres de resistència activa ${ }^{48}$.

Encara que, normalment, quan la part musulmana posava el cas en mans d'un oficial cristià i no sarraí era perquè la defensa percebia que, en cas d'aplicar-se la llei cristiana, la part musulmana en sortiria més afavorida perquè les normes punitives eren menys severes ${ }^{49}$, les raons per preferir els tribunals cristians també podien justificar-se, com en el cas d'Elx, en funció dels problemes interns a les aljames o amb les estructures judicials d'aquestes. La connivència de l'alfaquí Alhaig amb les autoritats cristianes d'Elx no sembla tenir cap més explicació que aquesta.

Per tant, l'estratègia va fallar quan, com a Elx, en funció dels problemes interns de les aljames o dels problemes amb les seves estructures judicials, alguns sarraïns preferiren recórrer als tribunals cristians.

Tanmateix, ens sembla evident que a Elx degué arribar-se a extrems exagerats de sagnia econòmica dels sarraïns. Sinó, no s'explicaria que, en la

46. Vegeu A. Domingo, La criminalitat..., vol. II, 427 i següents.

47. Ibidem, 435-437.

48. Ibidem, 442 .

49. Ibidem, 447-448. 
resolució dels consellers de Barcelona que introdueix la insaculació en l'elecció dels vells i del consell dels deu de l'aljama, s'incidís tan clarament en les despeses que ocasionaven la pèrdua de jornals dels sarraïn, fins a arribar a prohibir que, en endavant, seguissin pledejant per escrit ${ }^{50}$.

En definitiva, podem dir que, més enllà dels detalls quotidians o anecdòtics, tots aquests testimonis de sarraïns ens mostren, a través de la seva pròpia veu, que, a mitjan segle XV, l'aljama d'Elx, el que havia estat el nucli sarraí més important de les terres de la Governació d'Oriola, es trobava clarament debilitada i en evident decadència.

Als problemes derivats del domini cristià se li afegien les dissensions que la minaven des de dins, encara més greus, perquè, de totes totes, acabaven amb qualsevol possibilitat de cohesió i de reacció defensiva tant a nivell estructural com econòmic, social, polític i, en definitiva, aquí, demogràfic.

Míkel de Epalza escrigué que els cinc eixos d'acció de les comunitats sarraïnes en territori cristià foren reconèixer l'autoritat de fet del poder polític cristià, preservar una autonomia interna de la comunitat religiosa, amb les seves lleis i creences islàmiques pròpies, pagar impostos, suportar els abusos del poder cristià i fer tots els possibles per recuperar el poder polític ${ }^{51}$.

És evident que, a mitjan segle XV, 1'aljama d'Elx estava del tot sotmesa al reconeixement de l'autoritat política cristiana, al pagament d'impostos $\mathrm{i}$ als abusos del poder cristià.

Però, en canvi, era incapaç de fer front als dos eixos d'acció essencials per preservar la seva pròpia identitat i per conservar la seva cohesió interna i el seu orgull col-lectiu, perquè també era incapaç de preservar l'autonomia interna de la comunitat religiosa i d'intentar recuperar el poder polític.

$$
* * *
$$

\section{APÈNDIX DOCUMENTAL}

1449 , juny, 16. Elx.

Informació sobre diversos moros desaveïnats de la moreria d'Elx presa pel regent de l'ofici de la procuració general d'Elx $i$ Crevillent i el lloctinent de batlle de la ciutat de Barcelona a la mesquita de la moreria d'Elx a cinc sarraïns que s'havien traslladat a la Daia i a Albatera.

50. J.D. GARRIDO, «Barcelona...», 179.

51. M. de EpalZA, «Les morisques, vus à partir des Communautés Mudéjares précédentes», dins Les morisques et leur temps. Table ronde internationale (Montpellier 1981), Paris, CNRS, 1983, 38-39. 
A.H.C.B., Consellers - XX (Processos), caixa 1 B, núm. 21.

Informació dels moros que.s han dessavehinat de la moreria de la vila de Elg.

$\left\{\right.$ Dilluns, XVI dies del mes de juny, anno a nativitate Domini $\mathrm{M}^{\circ} \mathrm{CCCC}^{\circ} \mathrm{XXXX}$ VIIII\}

En aquest dia, en la vila de Elg, los honorables en Johan Farrandez de Mesa, regent lo offici de la procuració jeneral en la vila e en lo lloch de Crivillén per la molt insigne ciutat de Barcelona a , senyora dels dits vila e lloch, e en Galceran Zolivera, llochtinent del honorat $n^{\prime}$ Anthoni Balager, batle dels dits vila e lloch per la dita ciutat, com a sa audiència fos pervengut saber que en lo dia de hir certs moros de la moreria de la dita vila avien presentat albarans de vehinat, ço és, que-s serien fets vehins del lloch de Albatera e de la Daya, aldees de la ciutat de Oriola, desavehinant-se ${ }^{b}$ e mudant-se de la dita vila, per tal los dits procurador e llochtinent de batle, per provehir en quant en ells serà o fer poran que alguns altres moros no.s muden de la dita vila en altres parts e per saber encara les causes quines són per què los dits moros se són desavehinats e mudats, parlat de açò ab lo honorable en Gabriel Serradell, llochtinent de receptor de les rendes de la dita ciutat, en la dita vila resident, anaren personalment $\mathrm{ab} \mathrm{mi}$, Johan Gómiz, notari e scriva de la $\mathrm{a}^{\mathrm{c}}$ procuració e batlia de la dita vila e testimonis dejús a la moreria de la dita vila, e presents Hamet Albarrani, vell e jurat de la dita moreria, e Çaat Beoquexa, llochtinent de Cilim Zaem, altre vell de la dita moreria, los dits ${ }^{d}$ procurador e llochtinent de batle, dins la mezquita de la dita moreria, reeberen dels moros qui.s eren mudats de la dita moreria e fets vehins en altres parts e presentats en lo dia de hir sos albarans de vehinat la informació separadament dejús següent.

[a] Primo, fon rebuda informació de Mahomat Bornocia, àlies Marvà, moro de la dita moreria, el qual, en lo dia de huy, ha presentat albarà de vehinat del lloch de Albatera. $\mathrm{E}$ fon rebut jurament de aquell, girat vers l'Alquibla, segons çunya de serrahins, e promès dir veritat de ço que fos demanat.

$E$ fon demanat per los dits procurador e llochtinent de batle per quina o qual rahó se era mudat de la dita moreria. E dix e respòs que ell se era mudat de la dita moreria e avia pres vehinat del dit lloch de Albatera per rahon com ell no podia bastar als deutes que deu al collitor de Barcelona, ço és, de magram e de alfardes e de altres drets de senyor, e açò per tant com ell no ha collit en lo any present sinó cinch cafiç de civada e no pus blat, com l'any és estat de gran seccada, e no ha collit altres viures. E que lo collitor lo à congoxat. E que ell haga paguat, de drets a senyor, l'any present, cent sous $\mathrm{e}^{\mathrm{e}}$ e que li resten a paguar encara al collitor quaranta sous, dels quals dits quaranta sous lo dit collitor lo congoxa $\mathrm{e}$ ha congoxat tots dies que-l pach, e, per ço, com ell no ha pogut paguar la dita quantitat e lo any és stret, li à convengut de fer-se vehí de Albatera.

Fon interroguat si a ell, dit Mahomat, ha induhit o preguat alguna persona que se.n anàs a fer vehí del dit lloch de Albatera. E dix que no li avia dit neguna persona que se-n anàs ${ }^{\mathrm{f}}$ o ne prengués lo dit vehinat, salvu per ço que no pot paguar los dits deutes, e per ço com l'any és stret, a por que no curregue més deute.

\footnotetext{
a. Barcelona, abreviatura llatina a l'original, i així en endavant.

b. desavehinant-se, desavehinat-se a l'original.

c. segueix procuració de la ratllat.

d. segueix llochtinent ratllat.

e. sous, abreviatura llatina a l'original, i així en endavant.

f. segueix a fer vehí del dit lloch de Albatera e ratllat.
} 
Al qual dit Mahomat fon dit per los dits officials que, si ell volia aturar en la dita moreria, que ells lo farien comportar dels dits deutes. E lo dit Mahomat dix que acordaria.

[b] Ítem, fon rebuda informació de Amet Barrani, moro de la dita moreria, el qual ha presentat, en poder del dit llochtinent de batle, albarà de vehinat del lloch de Albatera en lo dia de hir, del qual fon rebut jurament vers l'Alquibla, segons çunya de serrahins, $\mathrm{e}$ promès dir veritat de ço que fos demanat.

E fon interroguat per quinag causa ell avia pres lo dit vehinat del dit lloch de Albatera. E dix que per ço avia pres lo dit vehinat com bonament no podia bastar a paguar los drets de senyor al collitor, e per rahon de les mesions que la moreria fahia. Emperò que ell, evans que presentàs lo dit albarà, avia comprat ab lo collitor e-l havia ga paguat.

Interroguat si-l avia algú induhit o preguat que prengués vehinat del dit lloch de Albatera, e dix que no.

Fon-li dit per los dits officials que, si ell volia aturar, que ells lo farien conportar dels dits deutes. E dix que no volia aturar, ans volia anar al dit lloch de Albatera.

[c] Îtem, fon rebuda informació de Çaat Catmar, àlies Castelló, moro de la dita moreria, el qual, en lo present dia de huy, à presentat albarà de vehinat del lloch de la Daya en poder del dit llochtinent de batle, lo qual jurà vers l'Alquibla, segons çunya de serrahins, e promès dir veritat de ço que fos demanat.

E fon interroguat per quina causa avia pres vehinat del dit lloch de la Daya. E dix que per eo com ell era menesterós e no podia bastar a paguar los deutes que devia a senyor, e que ha de paguar a Johan Vives sexanta hun sous. E que.l collitor havia venut lo mul per lo deute que deu a senyor. E per rahon de les mesions que la moreria fa. E que lo arrendador de la Daya, ço és, en Francesch ${ }^{\mathrm{h}}$ Pèriç, li prestava vint florins perquè paguàs los dits deutes e se-n anàs a la Daya.

Interroguat per quina causa ell no ha dit al procurador que lo collitor lo congoxava, que-l hagués fet comportar, e dix que ell ja ho dix a la aljama, e que la aljama ${ }^{i}$ li dix que lo procurador no podia fer conportar, e açò per tal com lo receptor congoxava lo collitor que.l fes paguar.

Interroguat si.lj avia algú induhit o preguat que·s fes vehí de la Daya, e dix que no.

Fon-li dit per los dits officials si volia aturar en la dita moreria, que ells lo ferien comportar dels dits seus deutes. E dix que no volia aturar.

[d] Ítem, fon rebuda informació de Mahomat Izmil, moro de la moreria de la dita vila, lo qual, en lo dia de hir, avia presentat, en poder del dit llochtinent de batle, albarà de vehinat del lloch de Albatera, lo qual jurà vers l'Alquibla, segons çunya de serrahins.

E fon interroguat per quina causa ell avia pres vehinat del lloch de Albatera. E dix que per ço com ell no pot bastar a paguar los seus deutes e mesions, e que lo collitor lo à congoxat de fer paguar los deutes que demana de les rendes. E, per semblant, diu que per

g. quina, deia què, -i- corregida sobre -è.

h. segueix Peiç ratllat.

i. segueix e que la aljama, repetit, ratllat.

j. segueix 1 , repetida, ratllada. 
rahó de les mesions que la moreria fa. E per rahon com li àn carreguat hun cap entregue en hun mul que té vell. E per rahon encara com ell té huna heretat en la Orta dels Moros de la dita vila e les gens fan-li camí per aquella dita heretat, e que se-n és clamat e que no·n pot obtenir justícia.

Interroguat si 1 avia algú induït que prengués vèhinat de Albatera, e dix que no.

Fon-li dit per los dits officials que, si volia aturar, que ells lo farien porroguar dels deutes que deu e li farien administrar justícia. E dix que, si.l porroguaven e li feyen justícia de la dita senda, que ell aturaria. E fon-li promès per los dits officials.

[e] Ítem, fon rebuda informació de Axer Tureytes, moro de la dita moreria, el qual, en lo dia de hir, avia presentat, en poder del dit llochtinent de batle, vehinat del lloch de la Daya, lo qual jurà vers l'Alquibla, segons çunya de serrahins, e promès dir veritat de ço que fos demanat.

E fon interroguat per quina causa o rahó ell se és fet vehí de la Daya. E dix e respòs que per ço com ell pagua molts drets a senyor e que no hi podia bastar a paguar los dits deutes. E que lo collitor lo congoxava molt tots dies e li venia les bèsties. Hoch encara diu que per ço com la moreria fa moltes mesions e que ell no.y pot bastar. E, noresmenys ${ }^{\mathrm{k}}$, diu que avia preguat e fet preguar a'n Guabriel Serradell, receptor, que-1 porroguàs algun poch per ço com era estat malalt, e que lo dit receptor ne lo collitor no.l avien volgut porroguar, ans, ab gran afany e treball, avia paguat cent sous al dit collitor e que encara li devia cent $\mathrm{e}$ vint sous, e que no.y pot bastar ne.y pot dar rahó.

Interroguat si és estat induhit per negú que.s fes vehí de la Daya, e dix que no.

Fon-li dit e promès per los dits officials que si ell volia aturar en la dita moreria que ells lo farien porroguar dels dits deutes. E dix que no volia aturar.

E, enseguides les dites coses, los dits procurador e llochtinent de batle, per ço com de aquest fet ells, dits procurador e llochtinent de batle, àn parlat ab lo dit en Gabriel Serradell, llochtinent de receptor, ço és, que per causa com los dits moros de la dita moreria són congoxats per ço com, a instància sua, lo collitor de les dites rendes fa paguar de ço que és degut a senyor ab efecte de la pagua de Nadal propasada, e per aquesta rahó lo dit llochtinent de receptor aja dit, presents los honrrats jurats de la dita vila, que ell és prest de porroguar o que sien conportats los moros qui, bonament, no poden paguar lo que resta de la dita pagua, aquells emperò que sia vist ésser impotents e no poder bastar a paguar a present la resta que deuen de la dita pagua, per ço los dits procurador e llochtinent de batle, per repòs de la dita moreria, e per conservar la població de aquella, e per què altres moros no.s muden de aquella per causa de no ésser comportats, provehiren ésser feta, migançant Jacme Crespo, misatgé seu, toca-trompeta, la crida infra següent ${ }^{\mathrm{m}}$.

Testimonis foren presents, a les coses damunt dites, en Bernat Quexans e en Fferrando Javaloyes, vehins de la vila de Elg.

Ara hojats que us fa hom a saber, de part dels honorables en Johan Ferrández de Mesa, donzell, ragent lo offici de la procuració jeneral de la vila de Elg e del lloch de

k. noresmenys, noresmeys a l'original.

1. segueix de la ratllat.

m. següent, següet a l'original. 
Crivillèn per la molt insigne ciutat de Barcelona, senyora dels dits vila e lloch, e en Galceran Zolivera, llochtinent del honorable n'Anthoni Balager, batle dels dits vila e lloch per la dita ciutat, a tots e qualssevol moros vehins de la dita vila e habitants en la moreria de aquella que dejen e sien tenguts paguar algunes quantitats a la senyoria de la dita vila o al collitor de les rendes de aquella de la pagua del Nadal pus propasada, que vinguen e sien devant lo dit procurador e llochtinent de batle, que ells són prests, degudament e rahonable e per aquell temps que rahonable serà, fer-los conportar e porroguar dels dits deutes que aquells deuen al dit collitor de les dites rendes, en manera tal que.ls serà fet degut comport.

En altra manera, si los dits moros fer no ho volrran o no ho curaran fer ne demanar, lo dit comport serà càrrech e culpa dels dits moros, com ells, dits procurador e llochtinent de batle, no saben qui o quals persones àn mester los dits comports o porroguació dels dits deutes.

Les quals dites coses e present crida los dits procurador e llochtinents de batle manaren ésser fets per la dita moreria per la indempnitat de la senyoria de la dita vila e per conservar la població de la dita moreria.

E, a poch estant del desús dit dia de dilluns, comptats XVI dies del mes de juny, lo dit Jacme Crespo dix e relació féu a mi, Johan Gómiz, notari e scriva desús dit, ell, en lo present dia de huy, aver feta la desús dita crida, de manament dels dits procurador e llochtinent de batle, per la moreria de la dita vila e llochs acostumats de aquella si e segons manat li fon desús e desús és inserta.

1449 , juny, 16 - juliol 23. Elx.

Informació sobre diversos moros desaveinats de la moreria d'Elx o que pensaven marxar-ne presa per dos jurats de la vila d'Elx en representació del Consell de la vila. Conté nou interrogatoris i la presentació de clam davant dels jurats per part d'altres cinc sarraïns de la moreria.

A.H.C.B., Consellers - XX (Processos), caixa 1 B, núm. 21.

\section{\{ Dilluns, XVI dies del mes de juny del any mil CCCC XXXX nou \}}

En est dia, los honrrats en Francesch Choverna e en Pere Quirant, jurats de la vila de Èlig, per certa proposició e notificació que, en dies passats, és estada feta, tenint conssell general en la sala o torre de la dita vila, ço és, que molts moros, per certes congoxes que.s dehia que.ls eren fetes, se eren deshavehinats de la dita vila e se-n eren anats e anaven a ffer-se vehins de altres parts, e que molts altres dels dits moros, vehins de la dita moreria, per semblant, estaven preparats de anar-se'n, e, si axí se havia de seguir, redundaria en gran dan de la dita vila, e, açò, per tant com la dita vila és fermança de les rendes planes pertanyents a la senyoria de aquella; per tal, lo dit honorable consell, per provehir degudament, lladonchs, en lo dit dia que la dita notificació fon feta, en lo dit conssell, verbalment hordenà e donà càrrech als dits jurats que, ab lo scriva de la sala de la dita vila, fahessen venir devant llur presència los moros que.s són fets vehins de altres parts e altres moros si sabran que-s vullen desavehinar, e aquells, ab tota diligència, interroguen curosament e interroguen e sàpien de aquells per qual rahó se'n van de la dita vila; e ço que per 
aquells serà respost sia continuat e façen continuar al dit scriva, per ço que, en aprés, ne puixen consultar als molt honorables senyors nostres, los conssellers de la molt insigne ciutat de Barcelona ${ }^{a}$, senyora de la dita vila.

Per ço, los dits jurats, volents metre e metent en execució lo manament del dit honorable conssell, en lo dia de huy, dejús scrit, faheren-se venir devant llur presència los moros dejús scrits, e reeberen de aquells la informació següent:

\section{$\{$ Dicta die et anno predicto \}}

[f] Hamet Albarrani, moro, vehí qui solia ésser de la vila de Èlig e ara vehí, novament, del lloch de Albatera, fon demanat e interrogat, per los dits honrrats jurats, per qual rahó se era desavehinat de la dita vila e se'n era anat de aquella.

Lo qual dix e respòs que ell, per pagar los magrams a la senyoria de la dita vila, no se.n hiria, car treballaria e pagaria segons ha costumat de fer.

Emperò diu que, per los grans ${ }^{b}$ pleyts que la moreria mena ${ }^{c}$, se fan grans messions e.s llançen alfardes, les quals diu que no pot bastar a pagar.

E que, per aquesta rahó, diu ell, dit Amet Albarraníd, que se-n és anat e s'és feyt vehí de Albatera.

Testimonis presents, en Francesch Sepulcre e en Johan Scamella, vehins d’Èlig.

$\{$ Dicta die et anno predicto $\}$

[g] Mahomat Porruig, àlies Marvà, moro, vehí qui solia ésser de la present vila e ara vehí de la Daya, ffon interrogat, per los dits honrrats jurats, per qual rahó se·n és anat e desavehinat de la dita vila.

E dix que ell sén va per ço com no pot bastar a pagar les alfardes que.s llançen en la present moreria per les messions que-s fan en pleyts e en misatgeries a Barcelona, e per altres despeses supèrflues que-s fan en la dita moreria.

E que, per aquesta rahó, se'n va.

Testimonis, en Johan Pérez, major, e en Barthomeu Granyana, sartre, e Amet Albarrani, vehins d'Èlig.

Dimarts, XXVII dies del mes de juny, any mil CCCC XXXX VIIII'.

[h] Çaat Tureytes, moro, vehí de la vila de Èlig, fon interrogat, per los dits honrrats jurats, per qual rahó se'n volia desavehinar de la dita vila.

E dix que per ço com ell té huna heretat en lo terme de la dita vila, pus de nou o deu anys ha que poseheje $e^{e}$ aquella, en la qual heretat diu que ha hun troç de olivar, lo qual troç de olivar lo batle de la dita vila lo.y ha llevat no sap per què, e lo ha donat a Açen

\footnotetext{
a. Barcelona, abreviatura llatina a l'original, $i$ així en endavant.

b. grans, corregit sobre magrams.

c. mena interlineat, escrit sobre me- han ratllat.

d. Albarrani, Albarrazi a l'original.

e. segueix A.? ratllat.
} 
Mocatden, moro. E per moltes vegades que aja request lo dit batle que li fahés justícia e li tornàs lo dit seu troç de olivar, e no.u ha volgut fer.

E, per aquesta rahó, diu el, dit Çaat, que se'n vol anar de la dita vila.

E diu més que tots anys ha acostumat bé de pagar los magrams e drets pertanyents a senyor, axí de la dita heretat com de les altres béns.

Testimonis, en Jacme Ortiz e en Esteve d'Ançano, vehins de la vila de Èlig.

$\left\{\right.$ Dilluns, a $X X X^{\text {af }}$ dies del mes de juny, anno a nativitate Domini millesimo $\mathrm{CCCC}^{\circ}$ $\left.X X X X^{\circ} V^{\prime} I I I I^{\circ}\right\}$

[i] \{Masquema, moro, vehí que solia ésser de la vila de Èlig, fon interrogat, per los dits jurats, per quina causa se-n és anat de la dita vila de Èlig e se era fet vehí de la ciutat de Oriola.

E dix que per causa com lo havien carregat de alfardes, que no.y podia bastar a pagar aquelles, per la qüestió del alfaquí e del alcadí. E que ell no sab rres dels feyts e no sab per què l'àn carregat de les dites alfardes.

E que, per aquesta rahó, se'n va de la vila de Èlig, e no per altres feyts.

Testimonis, Paulo de Aleuda e Barthomeu d'Elvado, major, vehins de la vila d'Èlig.

$\{$ Dicta die et anno predicto\}

[j] En Abdalla Ronçeret, morog, vehí que solia ésser de ${ }^{h}$ la vila de Èlig, fon interrogat, per $^{\mathrm{j}}$ los dits jurats, per quina causa se'n va de la vila de Ėlig e s'és feyt vehí de la ciutat de Oriola.

E dix que ell no se'n va per pagar les rendes de Barcelona, ans per les alfardes que diu que l'àn carregat per les qüestions que diu que són en la moreria.

$\mathrm{E}$, per aquesta rahó, se'n va, e no per altra.

Testimonis, en Bernat Quexans e en Barthomeu d'Elvado e en Pere Ferrández, forner, vehins d'Èlig.

$\left\{\right.$ Dicta ${ }^{j}$ die et anno predicto\}

[k] Axer Tureytes, moro, fon interrogat, per los dits jurats, que per qual rahó se.n és anat de la vila de Ėlig e s'és feyt vehí de Oriola.

E dix que per ço com Antequera, collidor del any passat, li demanava dinés e no.l podia $^{k}$ pagar. E que li dix lo dit Antequera que sén vengués ab ell a la presó.

\footnotetext{
f. a XXXa interlineat, escrit sobre XXVII ratllat.

g. moro interlineat.

h. segueix de ratllat.

i. fon interrogat per interlineat.

j. Dicta, Dita a l'original.

k. podia interlineat, escrit sobre volia ratllat.
} 
E més diu que prou ti que pagar de les rendes de Barcelona e que aja de pagar, de altra part, alfardes que l'àn carregat per $\operatorname{los}^{1}$ feyts de la moreria, e que no pot $^{\mathrm{m}}$ bastar a pagar tantes alfarde. E que per aquesta rahó se'n va de la dita vila de Èlig. E que totes aquestes alfardes fa carregar l'alfaquin

Testimonis, en Pere de Malla, en Bernat Quexans e en Bartomeu d'Elvado, vehins de la vila de Èlig.

\{ Dimarts, primer dia de juliol, any $X X X X V I m I^{\circ}$ \}

[1] Adducarim, moro, fon interrogat, per los dits jurats, per qual rahó se'n és anat de la vila de Èlig e s'és feyt vehí de Oriola.

E dix per ço com no pot bastar a pagar les missions que-s fan en la moreria lo alfaquí e les ${ }^{\circ}$ aljames. E que per aquesta rahó se.n va, e no per altra. Car dels feyts de la moreria diu que no.y sab rres e carreguen-li de les missions. E que gens no se.n va per pagar ço que pagava cascun any a senyor, sinó per les dites missions grans que fan los dits alfaquíp e aljames.

Testimonis, en Barthomeu d'Elvado, major, e en Johan Pérez, major, vehins de Èlig.

$\left\{\right.$ Dimarts, XXII q dies del mes de juli,ol any mil CCCC XXXXVIIII $\left.{ }^{\circ}\right\}$

[m] Amet Sarria, moro, vehí de Èlig, dix que ell posava clam davant los jurats, per ço com diu que no pot bastar a pagar les missions que-s fan en la moreria de la dita vila sobre lo fet del alfaquí.

E que, en ${ }^{r}$ les alfardes que llançen en la dita moreria, que ells ab ells ho tracten e.n fan que los altres no-n saben rres. Perquè diu que, si en aquests feyts no s'i proveeix, que ell se'n vol anar a fer vehí de altra part.

E que açò intima als jurats, que y proveesquen.

Testimonis, en Barthomeu d'Elvado e en Anthoni de Sentpere, vehins de Èlig.

\{ Dicta die et anno predicto \}

[n] Milich Xaep, moro, vehí d'Èlig, dix que posava clam davant los jurats, per ço com diu que ell ${ }^{\mathrm{s}}$ era dels deu de la aljama en l'any propassat, e lo alfaquí, a tracte seu e dels de la sua partida, ha tractat e ginyat, sens que l'altra part no.y ha sentit rres, ha feyt misatger e correus a Barcelona, que fan molt grans missions e despeses en la moreria, e llancen tant grans alfardes que no·y poden bastar a pagar aquelles, per los debats del dit alfaquí.

\footnotetext{
1. segueix fetes ratllat.

m. segueix $\mathrm{p}$ - ratllada.

n. alfaquí,-1- afegida posteriorment; entre les dues darreres linies, testimonis ratllat.

o. segueix ah- ratllat.

p. alfaquí, deia alfaquins, - ns ratllat.

q. XXII, deia XXIII, -I ratllat.

r. en interlineat.

s. segueix $\mathrm{d}$-ratllat.
} 
Perquè diu als dits jurats que.y proveesquen, car, en altra manera, se farà vehí de altra part

Hoch encara diu que la gent menuda se li clamava, de tots dies, dient que quins tractes són aquests que ell, que és dels deu de la aljama, no sabia rres de ${ }^{t}$ aquests afers. $\mathrm{E}$ que açò és gran despoblació de la moreria.

E més, que ell ha portat tres vehins cassats de la Xarch que, per amor d'ell, estan açí, e se.n foren anats si no per ell.

Perquè diu que, si en los dits feyts no s'i proveeix, que ell e los altres se faran vehins de altra part.

E més diu que ha sabut dels dits deu de la aljama que lo dit alfaquí, a tracte seu e ab los de la sua partida, tractà e ginyà que fosen donats a mossèn Ramon Çavall XX florins, los quals, lo dit alfaquí, ly féu donar. E que ell e altres cinch de la aljama no saberen rres.

Testes predicti.

( Dimecres, XXIII dies del mes de juliol, anno a nativitate Domini millesimo $\mathrm{CCCC}^{\circ}$ XXXX' VIIII $\left.^{\circ}\right\}$

[o] Çaat Albarrazi, moro, vehí de Èlig, dix que posava clam, davant los jurats, per ço com diu que ell era dels $X$ de la ${ }^{u}$ aljama del any passat e lo alfaquí, a tracte ${ }^{v}$ seu e dels de la sua partida, ha tractat e enginyat, sens que no.n han sentit rres, en fer misatgers e correus a Barcelona, que fan molt grans missions e despeses en la moreria, e llancen tant grans alfardes que no poden bastar a pagar aquelles per los debats del dit alfaquí. altra part.

Per què diu als dits jurats que.y proveesquen, car, en altra manera, se farà vehí de

E que la gent menuda se li clamava dient que quins tractes són aquests que ell, que era dels ${ }^{w}$ deu de la aljama, no sabia rres dels dits feyts. E que açò és gran despoblació de la moreria.

E, rresnomenys, diu que lo dit alfaquí, ab los de la sua partida, ha tractat e ginyat que fossen donats a mossèn Ramon Çavall vint florins, de la qual cosa ne congoixa molt la moreria.

Testimonis, en Jacme Buades e en Pere Çatorre, vehins d’Èlig.

$\{$ Dicta die et anno predicto $\}$

[p] Çaat Abençaot, moro, fon interrogat, per los dits jurats, per quina causa e rahó se-n és anat de la vila e s'és feyt vehí de Oriola.

Lo qual ${ }^{x}$ dix e respòs que ell se-n és anat per ço com diu que, moltes vegades, ha demanat justícia de alguns actes davant lo procurador e batle, e que no.n poty obtenir rres davant aquells.

\footnotetext{
t. segueix aquel- ratllat.

u. segueix aha- ratllat.

v. a tracte interlineat, escrit sobre a tractes ratllat.

w. segueix dels ratllat.

$\mathrm{x}$. segueix dií ratllat.

y. segueix de altra part ratllat.
} 
E que per aquesta causa se'n és anat de la dita vila.

E, rresnomenys, per fer-ly pagar les alfardes e missions no acostumades a pagar.

Testes predicti.

\section{$\{$ Dicta die et anno $\}$}

[q] Yuceff Alcadi, moro, vehí d'Èlig, dix que posava clam davant los jurats per ço com diu que ell era dels $X$ de la ${ }^{2}$ aljama en l'any passat, e sens que ell no·n sabé rres, lo alfaquí, a tracte seu e dels de la sua partida, ha tractat e ginyat, sens que no'n han sentit rres sinó tantsolament los de la sua companyia, en fer misatgers e correus a Barcelona, de què fan molt grans missions e despeses, e per aquesta causa llançen tant grans alfardes en la moreria que no poden bastar a pagar aquelles.

$\mathrm{E}$, açò, per los debat del dit alfaquí.

Perquè diu als dits jurats que-y proveesquen, car, en altra manera, ell entén a fer-se vehí de altra part.

E que molts moros de la moreria se li clamaven dient que ell era dels de la aljama no sabia rres de aquests affers.

E que, per açò, se seguirà gran despoblació de la moreria, segons fan de tots dies.

E que de tot açò és causa lo dit alfaquí.

Car, a tracte del dit alfaquí, féu donar a mossèn Ramon Çavall vint florins, sens que ell, que era dels deu de la aljama, no.n sentí rres. E altres de la dita moreria que no.n han sentit rres.

E més diu que, en la elecçió del mustaçaf, essent ja feyt en forma acostumada, fon elet en lo dit offici, ab consentiment del batle, Çat Albarrazi. E lo alfaquí, quant sabé que lo dit Çaat Albarrazi era almustaçaf e usava del dit offici, qualsque quinze dies havia pasats, lo dit alfaquí, a tracte e giny seu, féu grans missions e despeses per revocar al dit Albarrazi que no fos almustaçaf. Les quals missions se repartiren per la moreria, e carregà aquelles al poble. La qual alfarda diu que ${ }^{a a}$, segons és fama en la moreria, que pasa de doents reyals.

Testes predicti.

Dicta die et anno.

Ir] Çaat Abençof, moro, fon interrogat per quina causa se-n és anat de la moreria d'Èlig e s'és feyt vehí de la ciutat de Oriola.

E dix que per ço com ell, sentint les ${ }^{\mathrm{bb}}$ grans vexacions e burbulls e grans dans que de tots dies se feyen en la moreria de la dita vila e en la cort del batle, e com ell vehés que s'i feyen grans missions e despeses, axí de huna part com de altra.

$E$ veu que en ço que havia de jutgar lo alcadí ne feyen fer actes ab lo scriva del batle per donar guany a.quell.

z. segueix aha- ratllat.

aa. segueix és ratllat.

bb. les interlineat. 
$E$ que hun jorncc, congoxant la gent de aquestes despeses, ell, ensemps ab quinze altres moros, anaren davant lo honorable procurador e batle e açessor. E, essent davant aquells, los pregam e soplicam e requerim que ells nos volguessen jutgar segons nostra çunya e xara, per ço com en la xara no.y ha missions negunes e ja hi àalcadí salariejat que jutge los dits moros segons la dita çunya e xara. E que los dits procurador e batle ly resposseren que ells ho volien jutjar. E si ly venia bé. Sinó, que tres camins hi havia: que la hu anava a Oriola, e l'altre a Alacant ${ }^{\mathrm{dd}}$, e l'altre a la Vayll, e que preenguessen lo que's volguessen.

E diu que.s ti per agreujat del dit batle, per ço com era qüestió davant ell sobre dret de duana que muntava trenta sous e lo duaner posà.l en pleyt davant lo dit batle, la qual qüestió se podia determenar sens missions e segons és acostumat. E feren-ly que puja la dita qüestió, ab les missions, deu fflorins.

E, ítem, més avant, diu que.s té per agreujat del dit batle per ço com ly féu vendre huna cortina de seda que ly costà dotze fflorins. E féu-la vendre per cinch florins sens que no s'i servà la forma acostumada, ço és, que, quant se ven alguna cosa de moro, se ven a estimar a huyt dies. E tal pràtica se té huy.

E per les grans alfardes que, a tracte del alfaquí, se llançen en la moreria.

Perquè diu que, per aquestes vexaçions e altres, les quals serien llargues de scriure, se-n és anat de la dita vila e se és feyt vehí de la dita ciutat de Oriola \}

Testes predicti.

$\{$ Dicta die et anno $\}$

[s] Zoayra, muller de Alí Abençat Abençaot, alcadí de la moreria de Èlig, dix que posava ${ }^{\text {ee }}$ clam davant los jurats per ço com dix que-s tenia per agreujada dels honorables procurador e batle per ço com ly han pres ço del seu e los seus béns propis, car diu que, en los béns de la ${ }^{\text {ff }}$ dona, segons çunya e xara, no.s poden vendre.

E los dits procurador e batle fan-li vendre tots los béns, dient que tots són del alcadí. vendre.

Car diu que, segons la dita çunya, en los delgg açidach, no-ls pot toquar negú ne fer

Perquè requir als dits jurats que volien parlar ab los dits procurador e batle ly faeçen justícia e que la ${ }^{\text {hh }}$ vullen jutgar segons la sua çunya e xara $\}$

E, llesta la dita informació, com fos gran altercaçió en lo present consell per causa e rahó de la dita informació, ço és, que huns volien que fos tramesa a la ciutat de Barcelona, als senyors de conssellers, segons era reebuda, e altres volien que no-y fos tramesa per ço com la dita informaçió no era estada reebuda ab jurament reebuda dels dits moros.

E, estant axí alterquejant sobre la dita rahó, com fos en lo present conssell lo honrat en Pere Codines, àlies Sepulcre, dix que ell, com a llochtinent de reçeptor per lo honrat en

\footnotetext{
cc. jorn, corregit sobre jorm.

dd. a Alacant, manca a a l'original.

ee. segueix da- ratllat.

ff. segueix dita ratllat.

gg. segueix alcadí ratllat.

hh. segueix vol- ratllat.
} 
Jacme Serradell, reçeptor de les rendes de la dita vila, que de la dita informaçió reebuda per los dits jurats ly fos donat transllat per ço com lo volia trametre a sos senyors, los consellers de la dita ciutat, per ço que en lo dit fet proveesquen.

$\mathrm{E}$, rresnomenys, diu que ell, moltes e diverses vegades, en consells generals propassats, en nom del receptor, se és ${ }^{i i}$ offert, e en lo present conssell se offir, que ell és prest de sperar a qualsevulla moro que, per no pagar les rendes de senyor se'n vajaij o vulla anar de la dita ${ }^{\mathrm{kk}}$ vila tant e tant llongament tro que pusca pagar los dits drets, requirent que les dites coses fossen continuades en conseqüència dels presents actes $\}$

E lo dit honorable conssell manà a mi, Pere de Llorqua, notari e scriva del dit conssell, que de la dita infformaçió ly donàs transllat tota hora e quant lo·n volrrà.

$$
* * *
$$

\section{APÈNDIX ${ }^{1}$}

\section{NOMS DE CRISTIANS}

ALVADO, BARTOMEU D' (MAJOR): veí de la vila d'Elx, testimoni de les declaracions dels moros davant dels jurats d'Elx [D2].

ALVADO, BARTOMEU D': veí de la vila d'Elx, testimoni de les declaracions dels moros davant dels jurats d'Elx [D2].

ANÇANO, ESTEVE $D^{\prime}$ : veí de la vila d'Elx, testimoni de les declaracions dels moros davant dels jurats d'Elx [D2].

ANTEQUERA: collidor de les rendes de senyoria d'Elx de l'any 1448 [D2].

AULEDA, PABLO D': veí de la vila d'Elx, testimoni de les declaracions dels moros davant dels jurats d'Elx [D2].

BALAGUER, ANTONI: batlle de la vila d'Elx i del Iloc de Crevillent per la ciutat de Barcelona [D1].

BUADES, JAUME: veí de la vila d'Elx, testimoni de les declaracions dels moros davant dels jurats d'Elx [D2].

CODINES, PERE (ÀLIES SEPULCRE): lloctinent de receptor per Jaume Serradell, receptor de les rendes de la vila d'Elx [D2].

COLLIDOR: de les rendes d'EIx [D1].

CRESPO, JAUME: missatger i toca-trompeta del procurador i del lloctinent de batlle de la vila d'Elx i del lloc de Crevillent [D1].

\footnotetext{
ii. segueix offerit ratllat.

ij. segueix de la ratllat.

kk. dita interlineat.
}

1. [D1] indica que les persones referides apareixen al primer document; [D2] indica que apareixen al segon document. Les Iletres de la [a] a la [s] indiquen, quan es tracta de testimonis, llur referència en la transcripció dels documents. 
ESCAMILLA, JOAN: veí de la vila d'Elx, testimoni de les declaracions dels moros davant dels jurats d'Elx [D2].

FERNÁNDEZ, PERE: forner, veí de la vila d'Elx, testimoni de les declaracions dels moros davant dels jurats d'Elx [D2].

FERNÁNDEZ DE MESA, JOAN: procurador o regent de la procuració general a la vila d'Elx i al lloc de Crevillent per la ciutat de Barcelona; donzell [D1].

GÓMEZ (GÓMIZ), JOAN: notari i escrivà de la procuració i batllia de la vila d'Elx i del lloc de Crevillent [D1].

GOVERNA, FRANCESC: jurat d'Elx encarregat de rebre la informació dels moros [D2].

GRANYANA, BARTOMEU: sastre, veí de la vila d'Elx, testimoni de les declaracions dels moros davant dels jurats d'Elx [D2].

JAVALOYES, FERNANDO: veí de la vila d'Elx, testimoni de les declaracions dels moros a la mesquita [D1].

LLORCA, PERE DE: notari i escrivà del consell i jurats d'Elx [D2].

MALLA, PERE DE: veí de la vila d'Elx, testimoni de les declaracions dels moros davant dels jurats d'Elx [D2].

OLIVERA (ZOLIVERA), GALCERAN: lloctinent d'Antoni Balaguer, batlle de la vila d'Elx i del lloc de Crevillent per la ciutat de Barcelona [D1].

ORTIZ, JAUME: veí de la vila d'Elx, testimoni de les declaracions dels moros davant dels jurats d'Elx [D2].

PÉREZ, JOAN (MAJOR): veí de la vila d'Elx, testimoni de les declaracions dels moros davant dels jurats d'Elx [D2].

PERIS, FRANCESC: arrendador de la Daia, aldea de la ciutat d'Oriola [D1].

QUEIXANS, BERNAT: veí de la vila d'Elx, testimoni de les declaracions dels moros a la mesquita [D1]; veí de la vila d'Elx, testimoni de les declaracions dels moros davant dels jurats d'Elx [D2].

QUIRANT, PERE: jurat d'Elx encarregat de rebre la informació dels moros [D2].

SANTPERE, ANTONI DE: veí de la vila d'Elx, testimoni de les declaracions dels moros davant dels jurats d'Elx [D2].

SATORRE, PERE: veí de la vila d'Elx, testimoni de les declaracions dels moros davant dels jurats d'Elx [D2].

SAVALL, RAMON: el 28 d'agost de 1448 fou nomenat procurador d'Elx i Crevillent, però no va arribar a actuar perquè fou elegit conseller de Barcelona el 30 de novembre de $1448^{2}$ [D2].

SEPULCRE, FRANCESC: veí de la vila d'Elx, testimoni de les declaracions dels moros davant dels jurats d'Elx [D2].

SERRADELL, GABRIEL: lloctinent de receptor de les rendes de la ciutat de Barcelona (els moros l'anomenen receptor); resident a Elx [D1].

SERRADELL, JAUME: receptor de les rendes de la vila d'Elx [D2].

VIVES, JOAN: Çaat Catmar li deu 61 sous [D1].

2. Cf. J. F. CABESTANY, J. SOBREQUÉS, Elx i Crevillent t.., 630. 


\section{NOMS DE SARRAIINS}

ABENÇAOT, ÇAAT: declara el dia 23 de juliol davant dels jurats d'Elx [D2] [p].

ABENÇAT ABENÇAOT, ALI: alcadí de la moreria d'Elx; la seva muller, Zoayra, presenta clam davant dels jurats d'Elx el dia 23 de juliol [D2].

ABENÇOF, ÇAAT: declara el dia 23 de juliol davant dels jurats d'Elx [D2] [r].

ADDUCARIM: declara el dia 1 de juliol davant dels jurats d'Elx [D2] [1].

ALBARRANI, AMET: veí de la vila d'Elx, testimoni de les declaracions dels moros davant dels jurats d'Elx després d'haver declarat ell mateix [D2].

ALBARRANI, HAMET: vell i jurat de la moreria d'Elx [D1].

ALBARRANI, HAMET: declara el dia 16 de juny davant dels jurats d'Elx [D2] [f].

ALBARRAZI, ÇAAT: presenta clam davant dels jurats d'Elx el dia 23 de juliol; era dels deu de l'aljama de l'any anterior (1448) [D2] [o].

ALBARRAZI, ÇAAT: elegit mostassaf el 1448; quinze dies després que hagués començat a exercir el càrrec l'alfaquí aconseguí revocar la seva elecció [D2].

ALCADI, YUCEFF: presenta clam davant dels jurats d'Elx el dia 23 de juliol; era dels deu de l'aljama de l'any anterior (1448) [D2] [q].

BARRANI, AMET: declara el dia 16 de juny a la mesquita de la moreria d'Elx [D1] [b].

BEOQUEXA, ÇAAT: lloctinent de Cilim Zaem, vell de la moreria d'Elx [D1].

BORNOCIA, MAHOMAT (ÀLIES MARVÀ): declara el dia 16 de juny a la mesquita de la moreria d'Elx [D1] [a].

CATMAR, ÇAAT (ÀLIES CASTELLÓ): declara el dia 16 de juny a la mesquita de la moreria d'Elx [D1] [C].

IZMIL, MAHOMAT: declara el dia 16 de juny a la mesquita de la moreria d'Elx [D1] [d].

MASQUEMA: declara el dia 30 de juny davant dels jurats d'Elx [D2] [i].

MOCATDEN, ACEN: moro d'Elx a qui el batlle havia donat un oliverar que formava part d'una heretat de Çaat Tureytes [D2].

PORRUIG, MAHOMAT (ÀLIES MARVÀ): declara el dia 16 de juny davant dels jurats d'Elx [D2] [g].

RONCERET, ABDALLA: declara el dia 30 de juny davant dels jurats d'Elx [D2] [j].

SARRIA, AMET: presenta clam davant dels jurats d'Elx el dia 22 de juliol [D2] [m].

TUREYTES, AXER: declara el dia 16 de juny a la mesquita de la moreria d'Elx [D1] [e].

TUREYTES, AXER: declara el dia 30 de juny davant dels jurats d'Elx [D2] [k].

TUREYTES, ÇAAT: declara el dia 27 de juny davant dels jurats d'Elx [D2] [h].

XAEP, MILICH: presenta clam davant dels jurats d'Elx el dia 22 de juliol; era un dels deu de l'aljama de l'any anterior (1448) [D2] [n].

ZAEM, CILIM: vell de la moreria d'Elx [D1].

ZOAYRA: muller d'Ali Abençat Abençaot, alcadí de la moreria d'Elx; presenta clam davant dels jurats d'Elx el dia 23 de juliol [D2] [s]. 


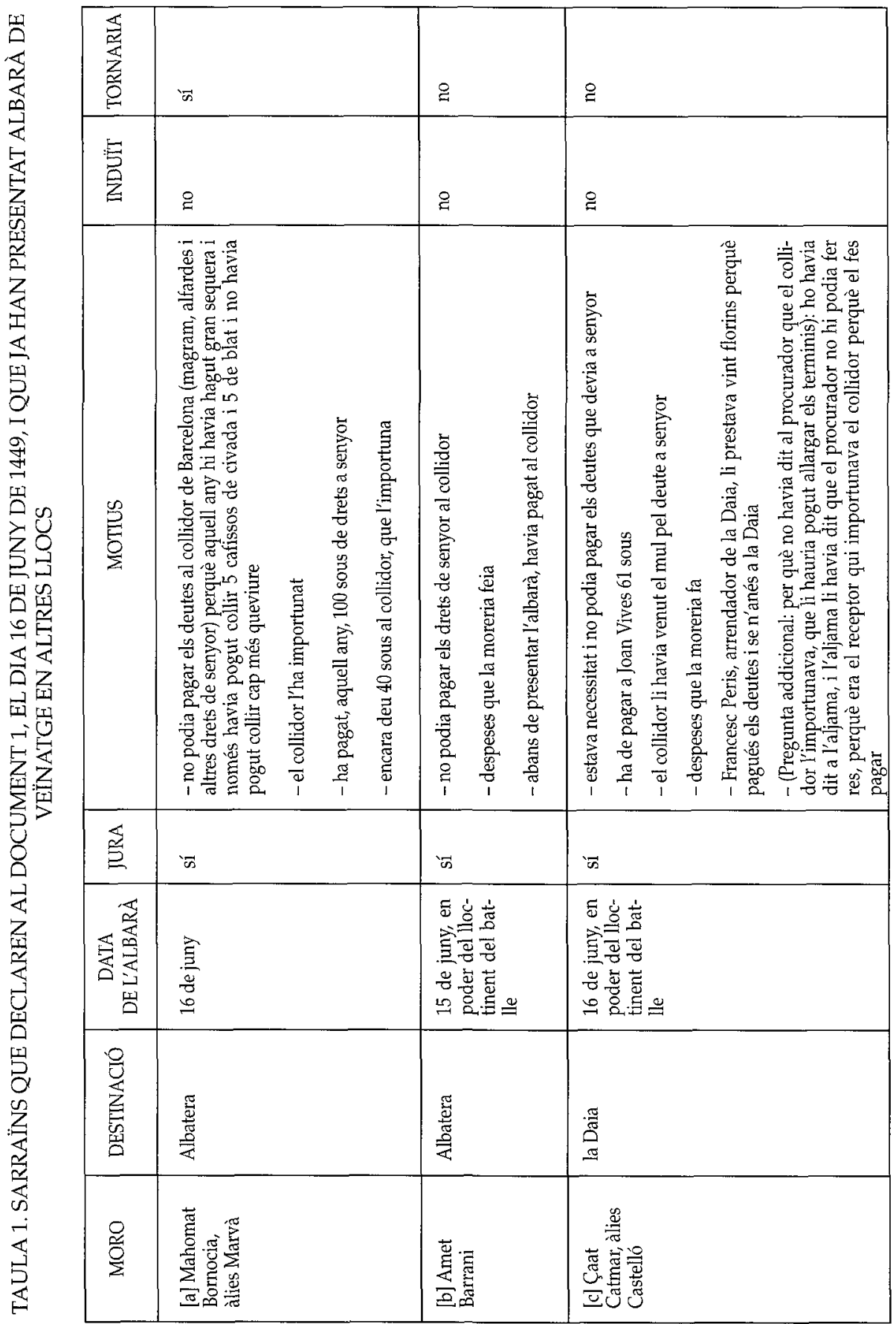




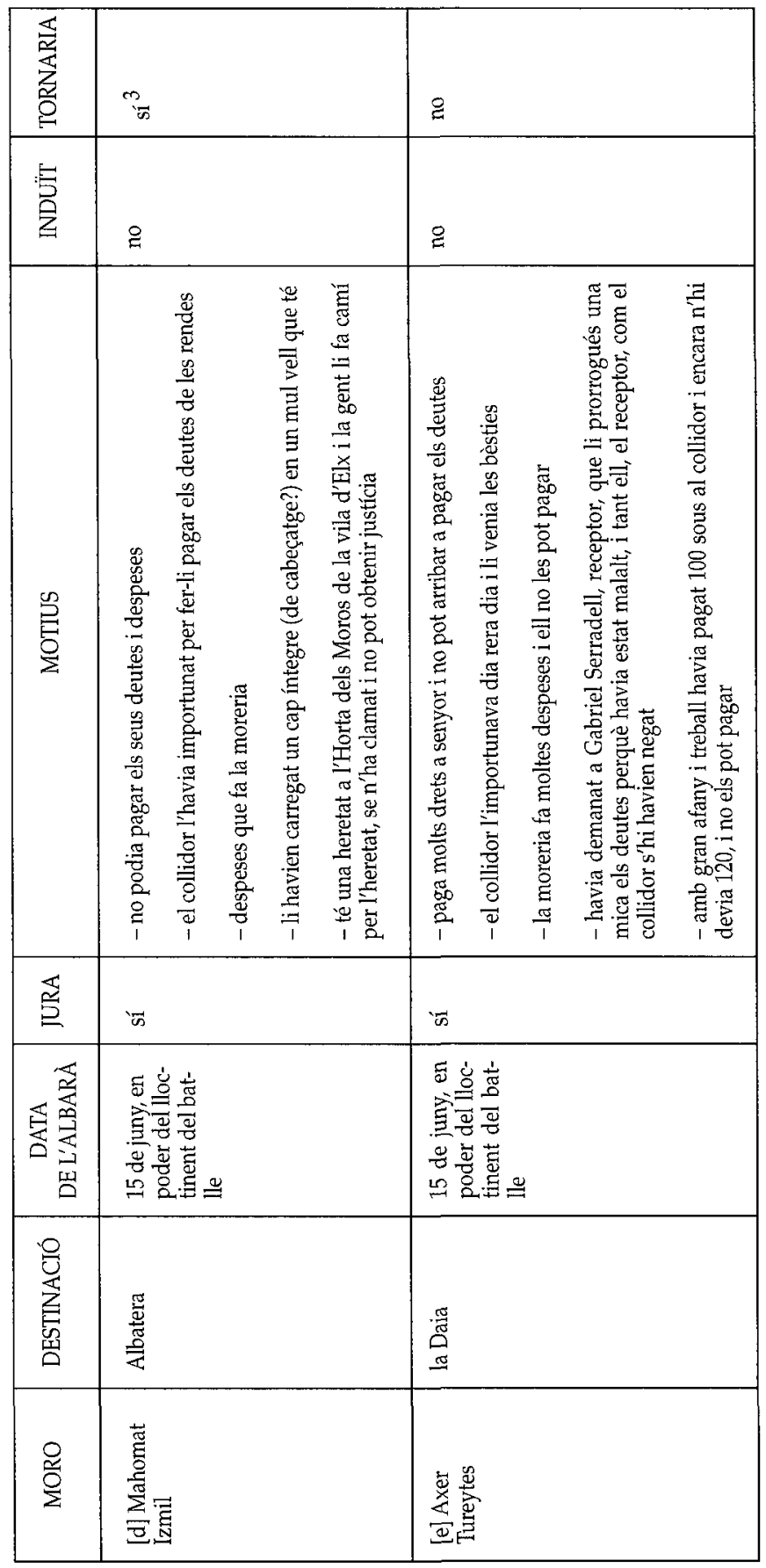




\begin{tabular}{|c|c|c|c|c|c|c|c|c|c|}
\hline 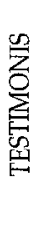 & 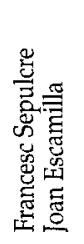 & & 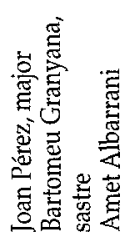 & 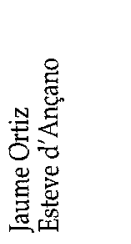 & & 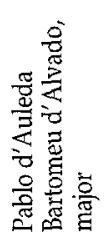 & 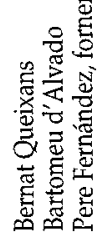 & 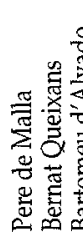 & \\
\hline$\frac{\text { 号 }}{\stackrel{5}{5}}$ & 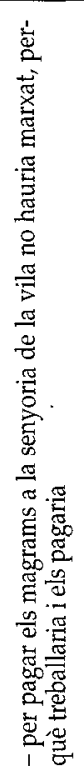 & 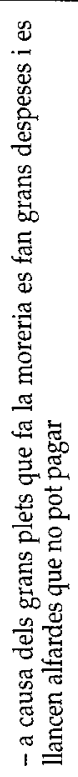 & 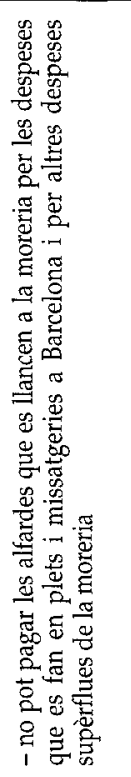 & 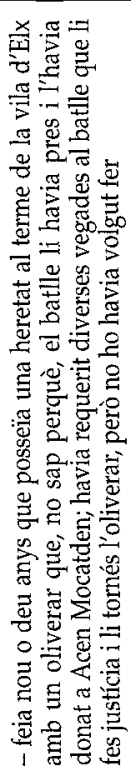 & 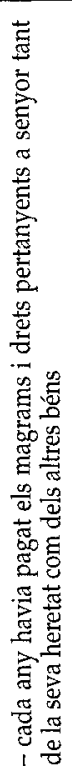 & 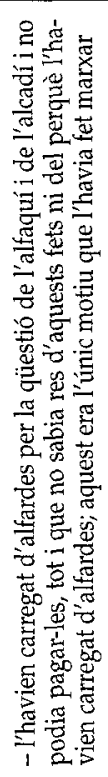 & 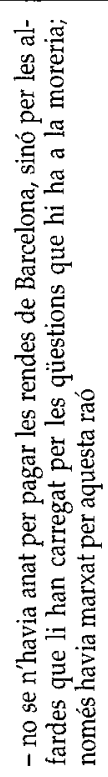 & 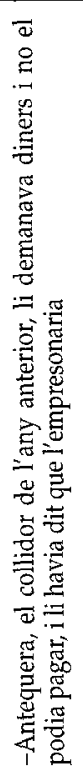 & 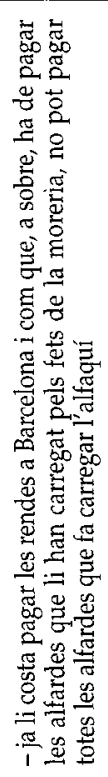 \\
\hline $\begin{array}{l}\mathscr{O} \\
ٍ ్ త\end{array}$ & 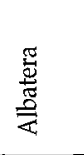 & & 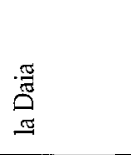 & 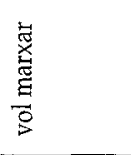 & & $\frac{\pi}{5}$ & $\frac{\frac{\pi}{6}}{\frac{0}{0}}$ & $\frac{\pi}{8}$ & \\
\hline 蒠 & $\begin{array}{l}\frac{\vec{g}}{2} \\
\frac{8}{0} \\
\sim\end{array}$ & & $\begin{array}{l}\stackrel{2}{0} \\
\stackrel{0}{8} \\
\stackrel{0}{0}\end{array}$ & $\begin{array}{l}\text { 害 } \\
\text { సे }\end{array}$ & & 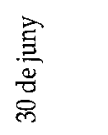 & $\frac{\overrightarrow{3}}{\frac{D}{8}}$ & 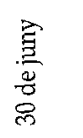 & \\
\hline 尽 & 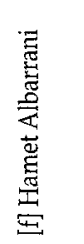 & & 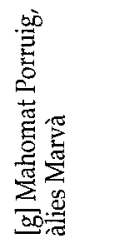 & 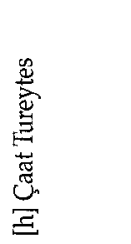 & & 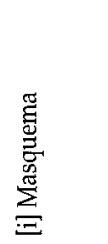 & 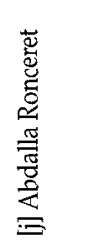 & 离 & \\
\hline
\end{tabular}




\begin{tabular}{|c|c|c|c|c|c|c|c|c|c|}
\hline $\begin{array}{l}\text { 先 } \\
0 \\
\text { 音 } \\
\text { 兽 }\end{array}$ & 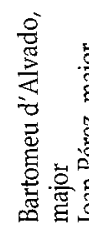 & & & 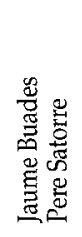 & & 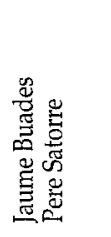 & & & \\
\hline$\frac{2}{3}$ & 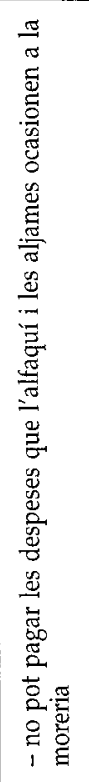 & 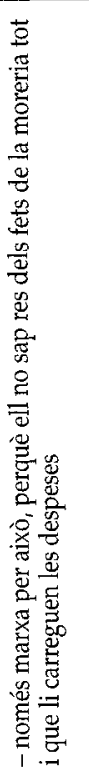 & 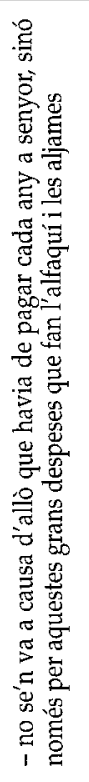 & 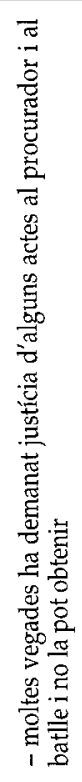 & 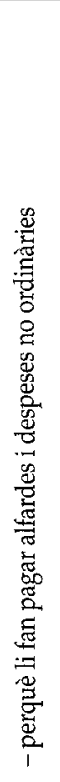 & 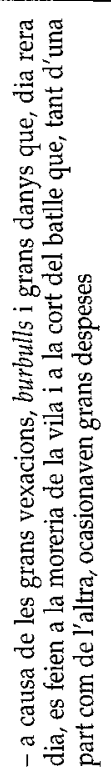 & 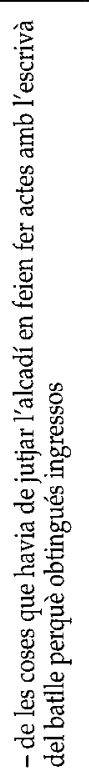 & 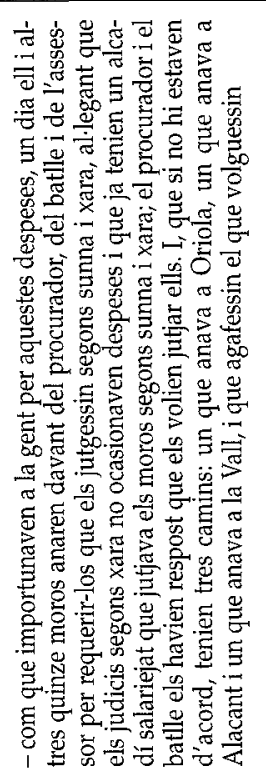 & 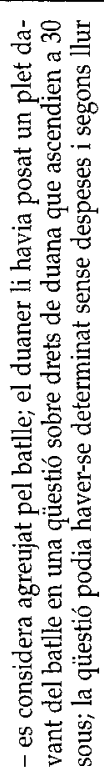 \\
\hline 总 & \multicolumn{3}{|l|}{ 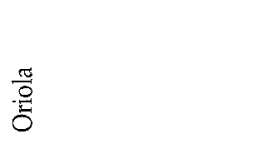 } & \multicolumn{2}{|l|}{$\frac{\pi}{\frac{\pi}{g}}$} & \multicolumn{4}{|l|}{$\begin{array}{l}\frac{\pi}{0} \\
\frac{0}{2}\end{array}$} \\
\hline 索 & \multicolumn{3}{|l|}{ 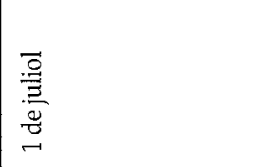 } & \multicolumn{2}{|l|}{ 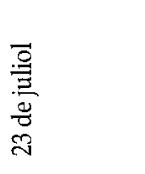 } & \multicolumn{4}{|l|}{ 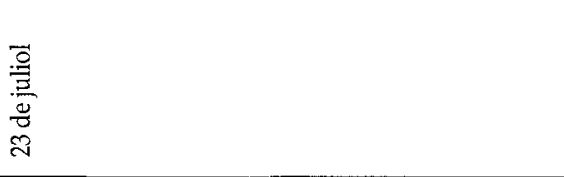 } \\
\hline 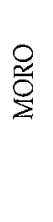 & \multicolumn{3}{|l|}{ 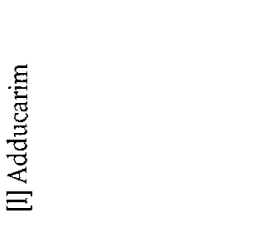 } & 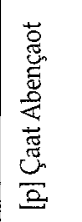 & & \multicolumn{4}{|l|}{ 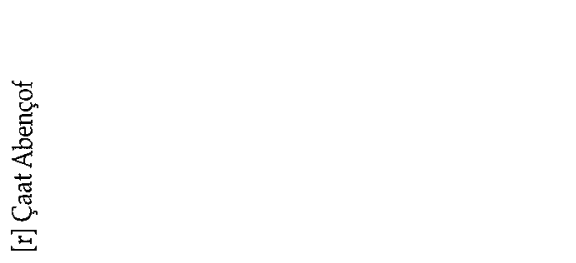 } \\
\hline
\end{tabular}




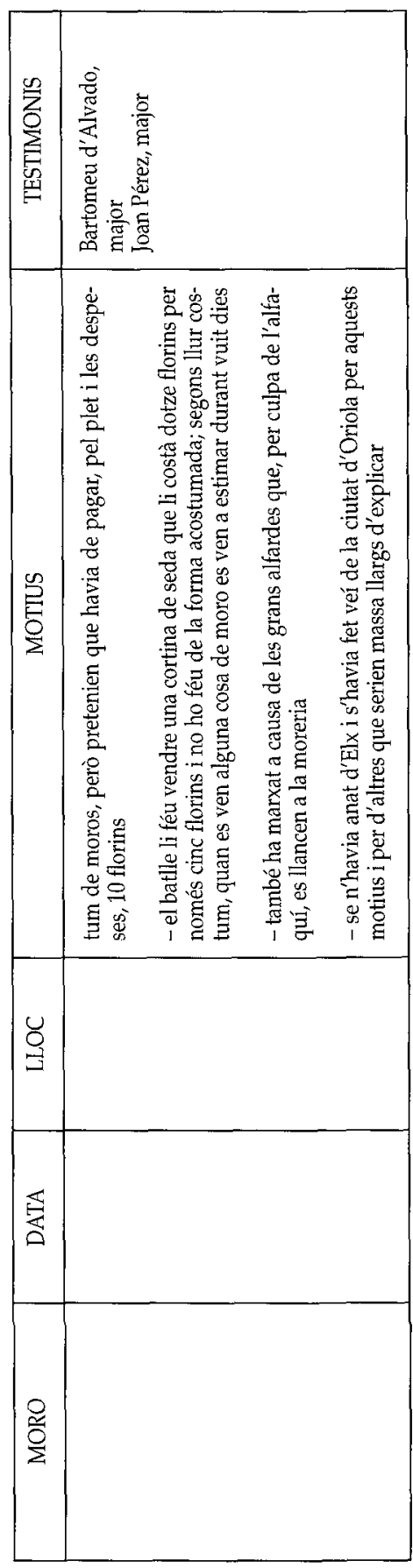




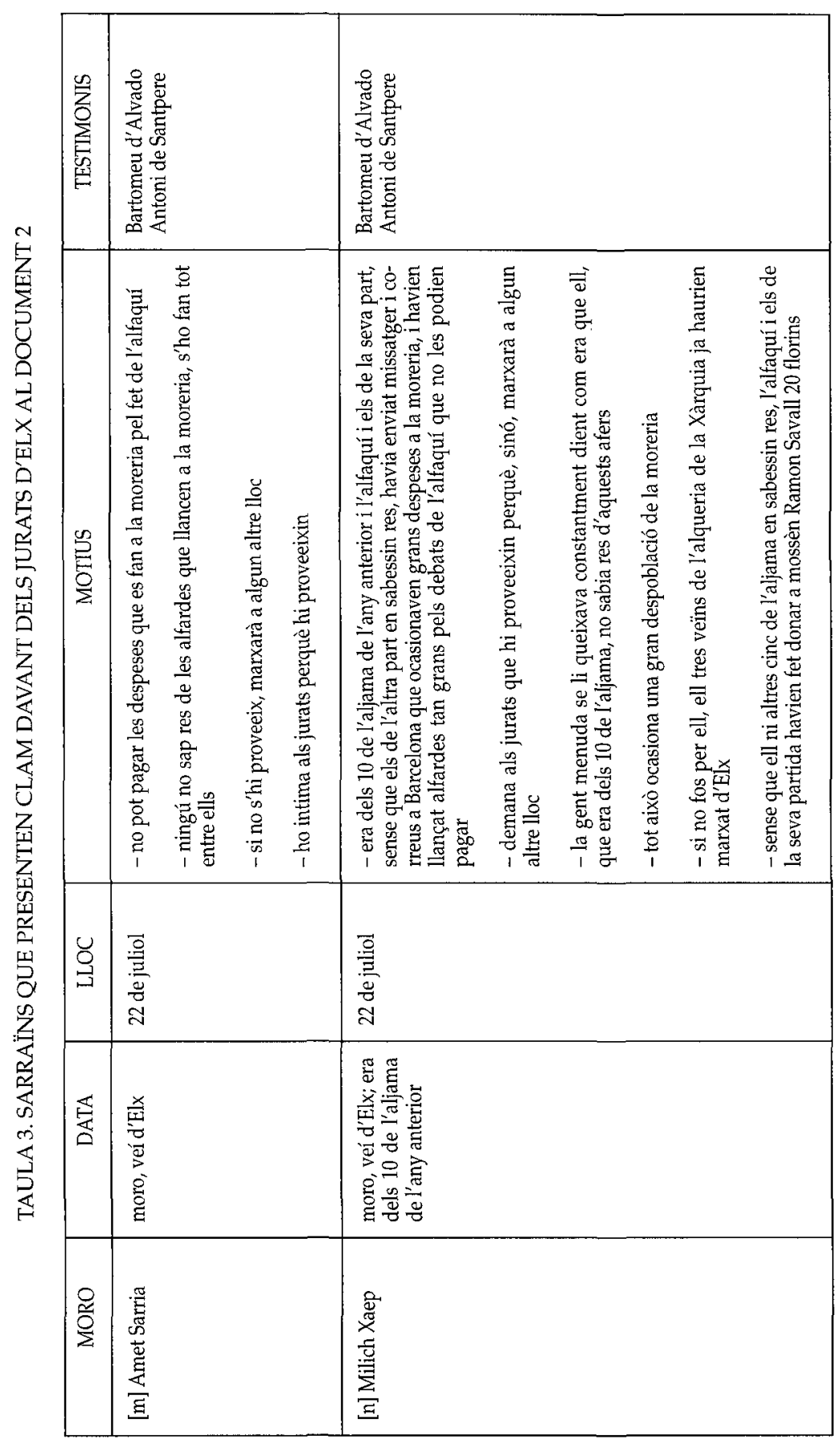




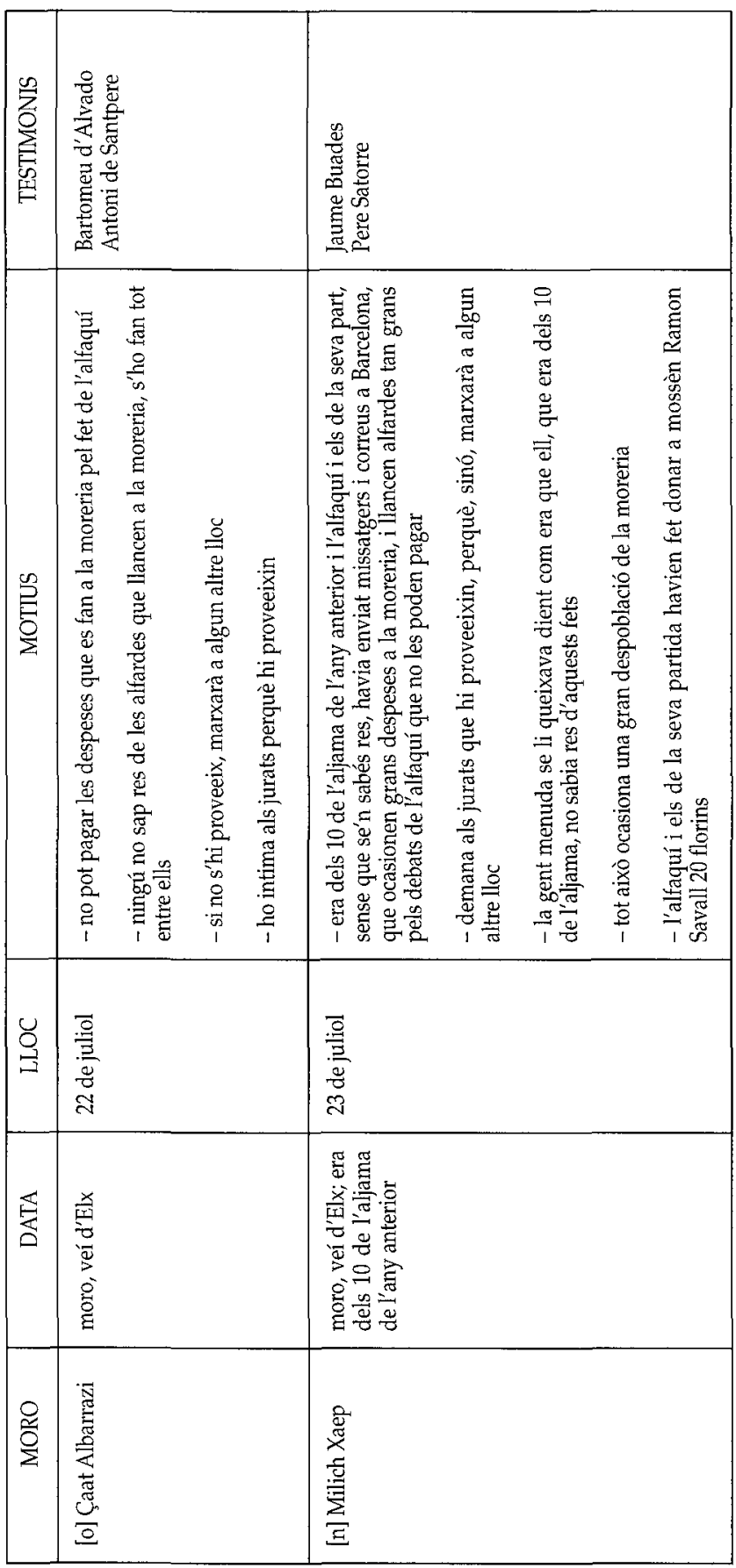




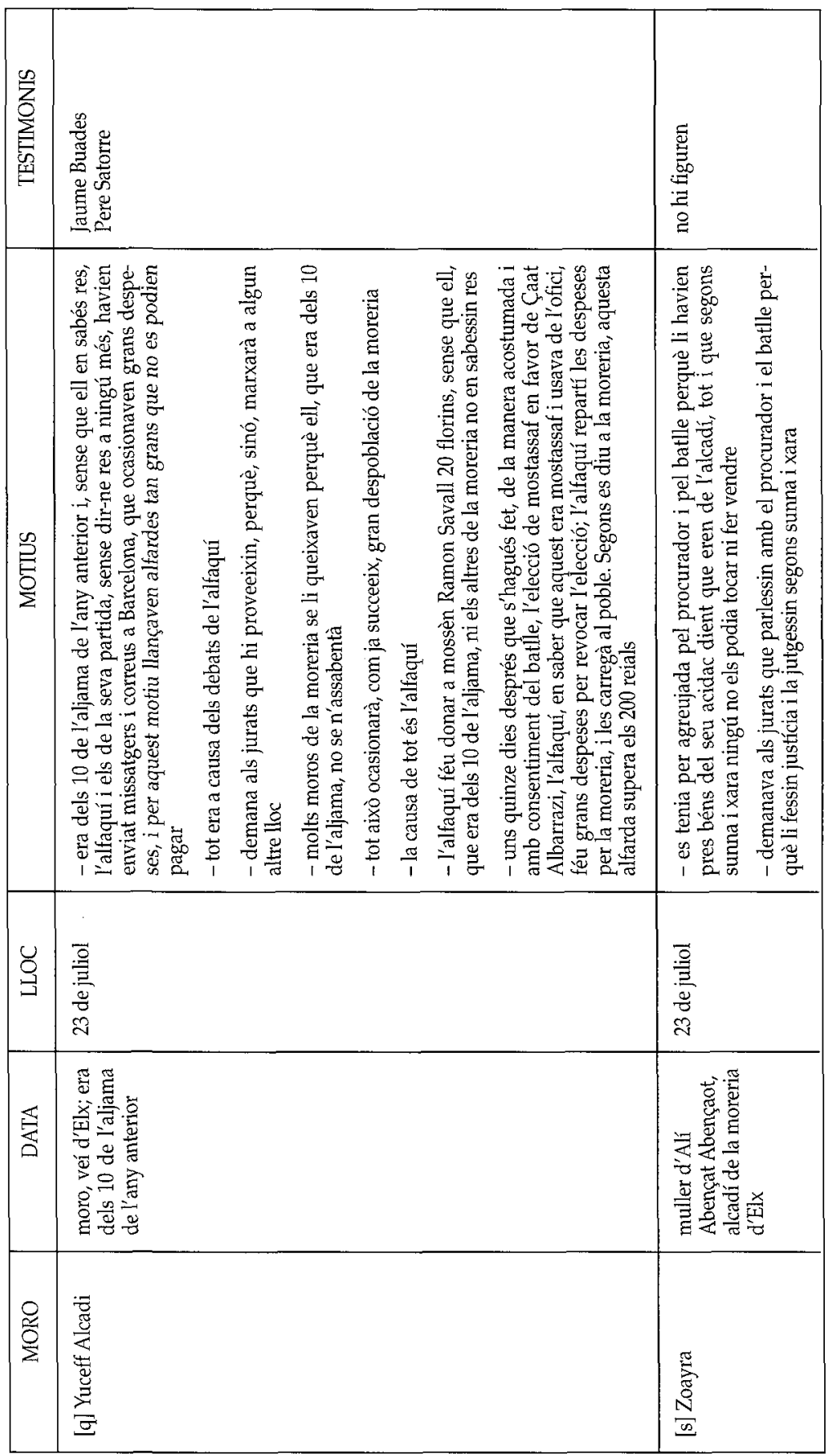

